\title{
Total-Evidence Framework Reveals Complex Morphological Evolution in Nightbirds (Strisores)
}

\author{
Albert Chen ${ }^{1,2, *} \mathbb{C}$, Noor D. White ${ }^{3,4} \oplus^{-}$, Roger B.J. Benson ${ }^{5}$, Michael J. Braun ${ }^{3,4}(\mathbb{D}$ and \\ Daniel J. Field $2, *$ (D) \\ 1 Milner Centre for Evolution, University of Bath, Bath BA2 7AY, UK \\ Department of Earth Sciences, University of Cambridge, Cambridge CB2 3EQ, UK \\ 3 Department of Vertebrate Zoology, MRC 163, National Museum of Natural History, Smithsonian Institution, \\ Washington, DC 20013, USA \\ 4 Behavior, Ecology, Evolution and Systematics Program, University of Maryland, College Park, \\ MD 20742, USA \\ 5 Department of Earth Sciences, University of Oxford, Oxford OX1 3AN, UK \\ * Correspondence: a.chen@bath.ac.uk (A.C.); djf70@cam.ac.uk (D.J.F.)
}

Received: 7 August 2019; Accepted: 22 August 2019; Published: 23 August 2019

\begin{abstract}
Strisores is a clade of neoavian birds that include diurnal aerial specialists such as swifts and hummingbirds, as well as several predominantly nocturnal lineages such as nightjars and potoos. Despite the use of genome-scale molecular datasets, the phylogenetic interrelationships among major strisorean groups remain controversial. Given the availability of next-generation sequence data for Strisores and the clade's rich fossil record, we reassessed the phylogeny of Strisores by incorporating a large-scale sequence dataset with anatomical data from living and fossil strisoreans within a Bayesian total-evidence framework. Combined analyses of molecular and morphological data resulted in a phylogenetic topology for Strisores that is congruent with the findings of two recent molecular phylogenomic studies, supporting nightjars (Caprimulgidae) as the extant sister group of the remainder of Strisores. This total-evidence framework allowed us to identify morphological synapomorphies for strisorean clades previously recovered using molecular-only datasets. However, a combined analysis of molecular and morphological data highlighted strong signal conflict between sequence and anatomical data in Strisores. Furthermore, simultaneous analysis of molecular and morphological data recovered differing placements for some fossil taxa compared with analyses of morphological data under a molecular scaffold, highlighting the importance of analytical decisions when conducting morphological phylogenetic analyses of taxa with molecular phylogenetic data. We suggest that multiple strisorean lineages have experienced convergent evolution across the skeleton, obfuscating the phylogenetic position of certain fossils, and that many distinctive specializations of strisorean subclades were acquired early in their evolutionary history. Despite this apparent complexity in the evolutionary history of Strisores, our results provide fossil support for aerial foraging as the ancestral ecological strategy of Strisores, as implied by recent phylogenetic topologies derived from molecular data.
\end{abstract}

Keywords: Strisores; avian; phylogeny; evolution; morphology; total-evidence

\section{Introduction}

Strisores is a clade of neoavian birds that includes Caprimulgidae (nightjars), Steatornithidae (the monotypic Oilbird), Nyctibiidae (potoos), Podargidae (frogmouths), Aegothelidae (owlet-nightjars), Hemiprocnidae (treeswifts), Apodidae (swifts), and Trochilidae (hummingbirds) [1-3]. Though the nocturnal and crepuscular clades of strisoreans (Caprimulgidae, Steatornithidae, Nyctibiidae, 
Podargidae, and Aegothelidae) were formerly classified as a single group "Caprimulgiformes", the most recent analyses of both morphological and molecular data recover this traditional concept of "Caprimulgiformes" as a paraphyletic assemblage with respect to Apodiformes (Hemiprocnidae, Apodidae, and Trochilidae) [1-10]. Among the traditional "Caprimulgiformes", Aegothelidae is routinely found to be the extant sister taxon of Apodiformes, and the clade uniting both has been named Daedalornithes [11]. This indicates that apodiforms may represent a reversion to diurnal habits from a nocturnal ancestor $[2,6,10,12]$.

Other than the strongly-supported monophyly of Daedalornithes, the phylogenetic relationships among major strisorean clades have remained contentious (Figure 1). Several molecular analyses have found strisorean interrelationships challenging to resolve, recovering little support for any specific phylogenetic topology (e.g.: [5,6]). The morphological analysis of Mayr [2] found Steatornithidae, Podargidae, and (Caprimulgidae + Nyctibiidae) to be successively more closely related to Daedalornithes. A similar topology was recovered by the morphological analysis of Ksepka et al. [8], the only difference being that Podargidae was recovered as the extant sister group of Steatornithidae. The phylogenomic analysis of Hackett et al. [1] also found a similar result to that of Mayr, but differed in placing Nyctibiidae as the extant sister group of Steatornithidae. Other molecular studies have offered alternatives with more dramatic differences: Reddy et al. [9] found (Steatornithidae + Nyctibiidae), Caprimulgidae, and Podargidae to be successively more closely related to Daedalornithes, whereas Prum et al. [3] instead found (Steatornithidae + Nyctibiidae) as the sister group of (Podargidae + Daedalornithes), with Caprimulgidae being the extant sister group to the rest of Strisores. White and Braun [10] recovered a topology identical to that of Prum et al. using an alternative molecular dataset.

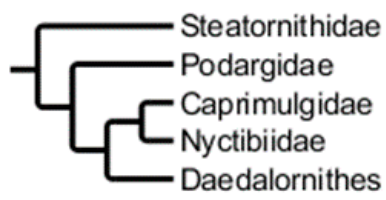

Mayr (2010)

69 morphological characters

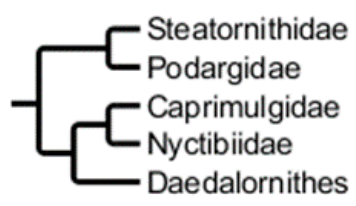

Ksepka et al. (2013)

117 morphological characters

6,064 nucleotide base pairs

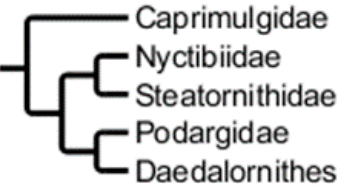

Prum et al. (2015) 394,683 nucleotide base pairs

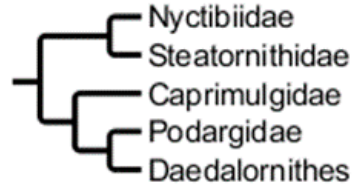

Reddy et al. (2017) 137,463 nucleotide base pairs

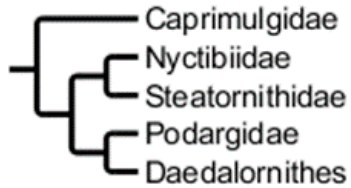

White and Braun (2019) $4,110,801$ nucleotide base pairs

Figure 1. Alternative hypotheses for the phylogenetic topology of Strisores suggested by previous studies.

A total-evidence approach combining both molecular and morphological sources of data has the potential to assist in resolving this phylogenetic uncertainty. Such an approach has been previously applied to other controversies in vertebrate systematics, such as the phylogeny of actinopterygian fishes [13-16], placental mammals [17,18], and squamate reptiles [19]. Total-evidence datasets allow for the inclusion of morphological information preserved in the fossil record. This can, in turn, improve phylogenetic resolution by shedding light on the ancestral morphologies of highly apomorphic lineages, thus potentially uncovering support for clades whose synapomorphies are no longer obvious in the anatomy of their extant representatives [20-26]. In addition, a robust understanding of the phylogenetic affinities of fossil taxa is often critical for the accurate estimation of phylogenetic divergence times [27-29]. 
Strisores has a rich Paleogene fossil record [30,31]. Possible representatives of nearly all major strisorean lineages have been identified from Paleogene fossils, including putative stem-oilbirds [32,33], stem-potoos [34], stem-frogmouths [35-37], stem-apodiforms [8,38], stem-swifts [39], and stem-hummingbirds [40-43]. In contrast, no convincing stem-owlet-nightjars from the Paleogene have previously been proposed [30].

The combination of uncertain phylogenetic interrelationships among the major subclades of Strisores and a well-represented Paleogene fossil record makes Strisores a worthy case study for evaluating the influence of morphological data in total-evidence analyses, as well as for clarifying morphological evolutionary patterns in crown-birds.

The present work represents the most comprehensive combined molecular and morphological phylogenetic analysis of Strisores. Ksepka et al. [8] presented a combined molecular and morphological analysis. However, their molecular dataset was small (consisting of 6064 nucleotide base pairs) and their resulting topology did not differ from that recovered by their morphology-only analysis. Herein, we present one of the largest phylogenetic datasets focused on Strisores to date by combining previously published morphological [8] and molecular [10] data matrices to produce a total-evidence framework for studying this phylogenetically intractable group of birds.

\section{Materials and Methods}

\subsection{Terminology and Clade Definitions}

To facilitate discussion of fossil taxa in relation to extant forms, herein we propose phylogenetic definitions for clade names that have been applied to members of Strisores (Appendix A). Phylogenetic definitions have only rarely been suggested for crown-group bird clades in the past, resulting in inconsistent application of clade names and establishment of redundant terms (e.g.: Strisores sensu Mayr [2] and Caprimulgimorphae of Jarvis et al. [44] refer to the same clade). The use of definitions here is intended to clarify the usage of taxonomic names in the present work and delimit the scope of equivalent names that have been previously coined.

Although it has been customary to use "-ine" as a suffix for the vernacular names of bird clades that end in "-es" (e.g.: neornithine as the vernacular form of Neornithes), Harris et al. [45] pointed out that "-ine" is generally reserved for the vernacular names of clades ending in "-inae" and that specialists focusing on other groups of organisms more commonly use "-ean" as the vernacularization of "-es". Following this argument, the present study applies the term strisorean as the vernacular form of Strisores, daedalornithean as the vernacular form of Daedalornithes, and so on. This modified terminology avoids confusion in the event that clade names which differ only in the suffixes "-es" and "-inae" are coined, and also brings ornithological terminology in line with the nomenclature used for other organisms.

\subsection{Phylogenetic Analysis}

We assembled a phylogenetic matrix comprising a morphological partition of 117 characters taken from Ksepka et al. [8] and a molecular partition of 2,353,369 nucleotide base pairs representing 2289 ultraconserved element loci (matrix "D4CU" from White and Braun [10]). Morphological character numbering follows that of Ksepka et al. [8], and eight morphological characters were treated as ordered. Our dataset includes 28 taxa, consisting of 11 extant strisoreans, 14 fossil strisoreans, and three extant outgroups. Our full character list and data matrices are available on Zenodo (http://doi.org/10.5281/zenodo.3351601). Extant taxon sampling is focused on taxa that had already been incorporated into both the morphological and molecular datasets, including the Oilbird (Steatornis caripensis, the only extant steatornithid), one nyctibiid (Nyctibius grandis), two podargids (Batrachostomus septimus and Podargus strigoides), one aegothelid (Aegotheles cristatus), one hemiprocnid (Hemiprocne mystacea), and two apodids (Aerodramus vanikorensis and Streptoprocne zonaris). Given that we did 
not have access to specimens of all taxa included in our dataset, we considered the addition of new morphological characters to be outside the scope of this study.

Of the major strisorean lineages, only Caprimulgidae and Trochilidae exhibited no overlap between the taxon sampling of both datasets. As such, we scored skeletal data for the caprimulgid Eurostopodus mystacalis and the trochilid Colibri coruscans. However, we did not have the opportunity to personally examine the soft tissues of these taxa, thus most characters pertaining to soft tissue were scored as unknown. In addition, the specimen of E. mystacalis we referenced, did not include the mandible or a complete vertebral series. Most mandibular characters could be scored based on photographs (including an image figured by Mayr [2]), but vertebral characters (chars. 37-42) for this taxon were scored as unknown. We were able to score several plumage characters (chars. 103, 105,106 , and 117) mainly by referencing photographs and Bostwick and Brady [46], as well as one behavioural character (char. 116) based on Handbook of the Birds of the World Alive [47]. Though rictal bristles (char. 103) were said to be absent in Eurostopodus by Mayr [2], Cleere [48] reports that they are present in reduced form, thus we scored this character as present for E. mystacalis.

As a second representative of Caprimulgidae, we also included a composite operational taxonomic unit (OTU), combining morphological data from Antrostomus carolinensis (the only caprimulgid previously included in the morphological dataset) and molecular data from Hydropsalis ("Lurocalis") rufiventris (the only caprimulgid other than Eurostopodus previously included in the molecular dataset). This decision was made because Caprimulgidae is one of the lineages whose phylogenetic position among Strisores is particularly uncertain, and as such increased taxon sampling is potentially critical for resolution of its relationships. Eurostopodus has been unambiguously recovered as the extant sister group to all other living nightjars in previous studies [6,49-51], thus Antrostomus and Hydropsalis are decidedly more closely related to each other than to any other taxon in our dataset, allowing for their treatment as a composite OTU. This also ensured that our sampling captured the deepest phylogenetic divergence within crown-group caprimulgids.

No taxon overlap was present in the outgroup choice for both datasets. The morphological dataset had used Crypturellus undulatus as the outgroup, whereas the molecular dataset used Anseranas semipalmata, Gallus gallus, and Columba livia. We chose to retain three outgroup taxa in our combined matrix, as these taxa include representatives from all three major clades of crown-birds originating from the deepest splits in crown-bird phylogeny: Palaeognathae (Crypturellus), Galloanserae (Anseranas), and Neoaves (Columba). As with Eurostopodus and Colibri, skeletal and some soft tissue characters were scored into the morphological dataset for Anseranas and Columba. Gallus gallus (another galloanseran) was excluded, as we did not have access to the skeleton of a wild-type individual. Accession numbers of all specimens examined are provided in Supplementary Text.

All 13 fossil members of Strisores included by Ksepka et al. [8] were retained in our combined matrix. A few character scores for Masillapodargus and Fluvioviridavis were modified based on observations made by Mayr [37] (see Supplementary Text). Hassiavis laticauda, an Eocene strisorean known from complete specimens but not yet included in any formal phylogenetic analysis, was scored into the matrix based on published descriptions [52,53]. A summary of current knowledge on the fossil strisorean taxa included in this study is presented in Table 1. 
Table 1. Summary of current knowledge on fossil strisoreans included in this study. Unless otherwise stated, age and locality information are based on Mayr [30], Ksepka and Clarke [54], and the original descriptions of the taxa listed.

\begin{tabular}{|c|c|c|c|c|}
\hline Taxon & Age & Locality & Described Material & $\begin{array}{l}\text { Recently } \\
\text { Hypothesized } \\
\text { Phylogenetic } \\
\text { Affinities }\end{array}$ \\
\hline $\begin{array}{l}\text { Hassiavis } \\
\text { laticauda Mayr, } \\
1998 \text { [52] }\end{array}$ & $\begin{array}{c}\text { Eocene } \\
\text { (Lutetian) }\end{array}$ & $\begin{array}{l}\text { Messel Formation, } \\
\text { Germany }\end{array}$ & $\begin{array}{c}\text { HLMD Me 9047a+b (nearly complete skeleton), } \\
\text { SMF-ME } 601 \text { (partial skeleton), SMF-ME 814a+b } \\
\text { (forelimb), SMF-ME 1772a+b (nearly complete skeleton) } \\
\text { [52], SMF-ME } 3545 \text { (complete skeleton) [53] }\end{array}$ & $\begin{array}{l}\text { "Cypselomorphae" } \\
\text { incertae sedis } \\
\text { (possibly closely } \\
\text { related to } \\
\text { Archaeotrogon) [53] }\end{array}$ \\
\hline $\begin{array}{l}\text { Protocypselomorphus } \\
\text { manfredkelleri } \\
\text { Mayr, } 2005 \text { [55] }\end{array}$ & $\begin{array}{c}\text { Eocene } \\
\text { (Lutetian) }\end{array}$ & $\begin{array}{l}\text { Messel Formation, } \\
\text { Germany }\end{array}$ & SMF-ME 11043 (nearly complete skeleton) [55] & $\begin{array}{l}\text { Stem-"cypselomorph" } \\
{[8,55]}\end{array}$ \\
\hline $\begin{array}{l}\text { Prefica nivea } \\
\text { Olson, } 1987 \text { [32] }\end{array}$ & $\begin{array}{l}\text { Eocene } \\
\text { (Ypresian) }\end{array}$ & $\begin{array}{l}\text { Green River } \\
\text { Formation, United } \\
\text { States }\end{array}$ & USNM 336278 (nearly complete skeleton) [32] & $\begin{array}{l}\text { Stem-steatornithid } \\
{[8,32,34,36]}\end{array}$ \\
\hline $\begin{array}{l}\text { Paraprefica } \\
\text { kelleri Mayr, } \\
1999 \text { [35] }\end{array}$ & $\begin{array}{l}\text { Eocene } \\
\text { (Lutetian) }\end{array}$ & $\begin{array}{l}\text { Messel Formation, } \\
\text { Germany }\end{array}$ & $\begin{array}{l}\text { SMF-ME } 3376 \text { (partial skeleton), SMF-ME 1635a+b } \\
\text { (complete skeleton), SMF-ME 1926 (hindlimb), SMF-ME } \\
2553 \text { (hindlimbs), SMF-ME 3377a+b (partial skeleton), } \\
\text { SMNK.PAL.938 (skull and fragmentary limbs) [35], } \\
\text { SMF-ME 3727a+b (complete skeleton), SMF-ME 3578 } \\
\text { (nearly complete skeleton), SMF-ME } 1760 \text { (forelimb) [34] }\end{array}$ & $\begin{array}{l}\text { Stem-nyctibiid } \\
{[8,34,36]}\end{array}$ \\
\hline $\begin{array}{l}\text { Fluvioviridavis } \\
\text { platyrhamphus } \\
\text { Mayr and } \\
\text { Daniels, 2001 } \\
\text { [56] }\end{array}$ & $\begin{array}{l}\text { Eocene } \\
\text { (Ypresian) }\end{array}$ & $\begin{array}{l}\text { Green River } \\
\text { Formation, United } \\
\text { States }\end{array}$ & $\begin{array}{l}\text { SMNK.PAL.2368a+b (nearly complete skeleton) [56], } \\
\text { FMNH PA } 607 \text { (partial skeleton) [36 }{ }^{1}\end{array}$ & $\begin{array}{c}\text { Stem-podargid } \\
{[8,36],} \\
\text { stem-“podargocypseli } \\
{[37]}\end{array}$ \\
\hline $\begin{array}{l}\text { Masillapodargus } \\
\text { longipes Mayr } \\
1999[35]\end{array}$ & $\begin{array}{c}\text { Eocene } \\
\text { (Lutetian) }\end{array}$ & $\begin{array}{l}\text { Messel Formation, } \\
\text { Germany }\end{array}$ & $\begin{array}{c}\text { SMNK.PAL.1083 (nearly complete skeleton), SMF-ME } \\
\text { 1415a+b (partial skeleton), SMNK.PAL.552a+b (skull), } \\
\text { SMNK.PAL.557 (skull), SMNK.PAL.2356a+b (skull), } \\
\text { SMF-ME 3404a+b (skull), SMF-ME 3405a+b (skull), } \\
\text { SMF-ME 3406 (skull) [35], HLMD Me 13359a+b (skull), } \\
\text { HLMD Me 7627a+b (partial skeleton), SMF-ME } 3658 \\
\text { (skull), SMF-ME } 3659 \text { (skull) [37] }\end{array}$ & $\begin{array}{l}\text { Stem-podargid } \\
{[8,35-37]}\end{array}$ \\
\hline $\begin{array}{l}\text { Eocypselus } \\
\text { vincenti } \\
\text { Harrison, } 1984 \\
\quad[57]\end{array}$ & $\begin{array}{l}\text { Eocene } \\
\text { (Ypresian) }\end{array}$ & $\begin{array}{l}\text { London Clay } \\
\text { Formation, United } \\
\text { Kingdom; Fur } \\
\text { Formation, } \\
\text { Denmark [58] }\end{array}$ & $\begin{array}{c}\text { NHM A } 5429 \text { (partial forelimbs and pectoral girdle) } \\
\text { [38,57], MGUH 26729 (partial skeleton), MGUH } 26730 \\
\text { (partial skeleton) [58], MGUH } 29278 \text { (nearly complete } \\
\text { imprint of skeleton) [38] }\end{array}$ & $\begin{array}{l}\text { Stem-apodiform } \\
{[8,38,40]}\end{array}$ \\
\hline $\begin{array}{l}\text { Eocypselus rowei } \\
\text { Ksepka et al., } \\
2013 \text { [8] }\end{array}$ & $\begin{array}{l}\text { Eocene } \\
\text { (Ypresian) }\end{array}$ & $\begin{array}{l}\text { Green River } \\
\text { Formation, United } \\
\text { States }\end{array}$ & WDC-CGR-109 (complete skeleton) [8] & Stem-apodiform [8] \\
\hline $\begin{array}{l}\text { Scaniacypselus } \\
\text { wardi Harrison, } \\
\quad 1984 \text { [57] }\end{array}$ & $\begin{array}{c}\text { Eocene } \\
\text { (Ypresian) }\end{array}$ & $\begin{array}{l}\text { Røsnæs Clay } \\
\text { Formation, } \\
\text { Denmark }\end{array}$ & NMHUK A 5430 (partial forelimb) [39,57] & $\begin{array}{c}\text { Stem-apodid } \\
{[8,39,40,55]}\end{array}$ \\
\hline $\begin{array}{l}\text { Scaniacypselus } \\
\text { szarskii (Peters, } \\
1985 \text { [59]) }\end{array}$ & $\begin{array}{c}\text { Eocene } \\
\text { (Lutetian) }\end{array}$ & $\begin{array}{l}\text { Messel Formation, } \\
\text { Germany }\end{array}$ & $\begin{array}{l}\text { SMNK Me } 301 \text { (nearly complete skeleton, SMF-ME } \\
\text { 606a+b (partial skeleton), SMF-ME } 599 \text { (partial skeleton), } \\
\text { HLMD Me 7598a+b (partial skeleton) [59], SMF-ME } \\
\text { 3576A (complete skeleton) [30,60], SMF-ME 11345a+b } \\
\text { (partial skeleton), SMF-ME 340a+b (complete skeleton), } \\
\text { SMF-ME 11413a+b (partial skeleton) [39] }\end{array}$ & $\begin{array}{l}\text { Stem-apodid } \\
{[8,39,40,55,61]}\end{array}$ \\
\hline $\begin{array}{c}\text { Parargornis } \\
\text { messelensis } \\
\text { Mayr, } 2003 \text { [62] }\end{array}$ & $\begin{array}{c}\text { Eocene } \\
\text { (Lutetian) }\end{array}$ & $\begin{array}{l}\text { Messel Formation, } \\
\text { Germany }\end{array}$ & HLMD Be 163+193 (complete skeleton) [62] & $\begin{array}{c}\text { Stem-trochilid } \\
{[8,40]}\end{array}$ \\
\hline $\begin{array}{c}\text { Argornis } \\
\text { caucasicus } \\
\text { Karhu, } 1999 \\
{[63]}\end{array}$ & $\begin{array}{l}\text { Eocene } \\
\text { (Bartonian) } \\
\text { [39] }\end{array}$ & Gorny Luch, Russia & PIN 4425-18 (partial skeleton) [63] & $\begin{array}{c}\text { Stem-trochilid } \\
{[8,40]}\end{array}$ \\
\hline $\begin{array}{l}\text { Jungornis } \\
\text { tesselatus Karhu, } \\
1988 \text { [64] }\end{array}$ & $\begin{array}{l}\text { Oligocene } \\
\text { (Rupelian) }\end{array}$ & $\begin{array}{c}\text { Maykop Formation, } \\
\text { Russia }\end{array}$ & PIN 1413/208 (partial forelimb and pectoral girdle) [64] & $\begin{array}{l}\text { Stem-trochilid } \\
{[8,40]}\end{array}$ \\
\hline $\begin{array}{l}\text { Eurotrochilus } \\
\text { inexpectatus } \\
\text { Mayr, } 2004 \text { [41] }\end{array}$ & $\begin{array}{l}\text { Oligocene } \\
\text { (Rupelian) }\end{array}$ & $\begin{array}{l}\text { Wiesloch-Frauenweiler, } \\
\text { Germany }\end{array}$ & $\begin{array}{l}\text { SMNS 80739/4+ SMNK.PAL.5591 (partial skeleton), } \\
\text { SMNS 80739/3a+b (partial skeleton) [41], } \\
\text { SMNK.PAL.4410a+b (partial skeleton) [65], } \\
\text { SMNK.PAL.6599 (partial skeleton) [66] }\end{array}$ & $\begin{array}{c}\text { Stem-trochilid } \\
{[8,41]}\end{array}$ \\
\hline
\end{tabular}

${ }^{1}$ Mayr [37] suggested that the two specimens referred to Fluvioviridavis platyrhamphus may not be conspecific. 
All analyses were conducted under a Bayesian phylogenetic framework in MrBayes $[67,68]$ using the CIPRES Science Gateway [69]. The morphological partition was analysed under the default Mk model [70], whereas the molecular partition was analysed under the GTR+G model [71]. The GTR+G model allows for substitution among all four nucleotide bases (unlike alternative models provided in MrBayes, such as HKY and F81) as well as gamma-distributed substitution rate variation across sites. Preliminary analyses also assuming gamma-distributed rate variation across the morphological partition failed to converge, as did runs that assumed inverse-gamma-distributed rate variation across the molecular partition. A variable rates model was applied, allowing the rates of molecular and morphological partitions to vary independently. Analyses were conducted using four chains and four independent runs, with a tree sampled every 1000 generations and a burn-in of $25 \%$. Following usage restrictions on CIPRES, analyses were monitored once a week and were terminated once they attained convergence. Convergence was assessed using standard diagnostics provided in MrBayes (average standard deviation of split frequencies $<0.02$, potential scale reduction factors $=1$, effective sample sizes $>200$ ) as well as graphically using Tracer v1.7.1 [72]. Results of independent runs of the same analyses were summarized using the sump and sumt commands in MrBayes. Morphological synapomorphies were optimized under parsimony onto resulting tree topologies using TNT [73].

Given that molecular data were not available for Crypturellus and our morphological dataset had not been designed to resolve the deepest splits in crown-bird phylogeny, topological constraints were implemented in our analyses so that representatives of Neognathae (Anseranas, Gallus, Columba, and Strisores) and Neoaves (Columba and Strisores) were forced to form those respective clades, avoiding inaccurate inferences of character polarity. These constraints were not applied to Analysis 1 , which only included taxa present in our molecular dataset (see below).

- Analyses 1-3: Morphological and molecular partitions run independently

To test the relative influence of our morphological and molecular data on inferred phylogenetic topologies, we ran separate analyses including only the molecular (Analysis 1) or morphological (Analysis 2) partitions. Taxa that had been scored for either molecular or morphological data only were excluded from each analysis as appropriate. Models and parameters specified for both analyses followed those previously described. Analysis 1 was run for 9,248,000 generations, whereas Analysis 2 was run for 30,000,000 generations.

Preliminary analyses of the morphological dataset failed to recover a monophyletic Apodi (Hemiprocnidae + Apodidae), and instead found Trochilidae and Apodidae as extant sister groups to the exclusion of Hemiprocnidae. Given that Apodi is found by all other recent studies of strisorean phylogeny [1-3,6-9], we also reran Analysis 2 with an added constraint to enforce its monophyly (Analysis 3). Fossil taxa were left unconstrained. This analysis was also run for 30,000,000 generations.

- Analysis 4: Total-evidence analysis (simultaneous analysis of molecular and morphological partitions)

This analysis was run for 11,288,000 generations using the total-evidence matrix described above.

- Analysis 5: Total-evidence analysis (morphological analysis with molecular scaffold)

In addition to simultaneously analysing molecular and morphological data in a combined dataset (as was done for Analysis 4), a second method for integrating different sources of phylogenetic data is to analyse only morphological data while enforcing a tree topology derived from molecular data with the topological position of fossil taxa left unconstrained [29]. We implemented such a molecular scaffold on the extant taxa in our morphological dataset based on the topology recovered by Analysis 1 (see Results below). The positions of fossil taxa were left unconstrained. This analysis was run for $30,000,000$ generations. 


\section{Results}

\subsection{Phylogenetic Topologies}

Analysis 1 (the independent molecular analysis) found Caprimulgidae, (Steatornithidae + Nyctibiidae), and Podargidae to be successively more closely related to Daedalornithes (Figure 2). This topology was also recovered in 5 out of 6 analyses of the same molecular dataset by White and Braun [10] and matches the topology of the overall best estimate of Strisores phylogeny proposed by that study. In addition, this topology is also identical to the results recovered by Prum et al. [3] based on independent molecular data. All nodes were supported by high $(>0.99)$ posterior probabilities (PP).

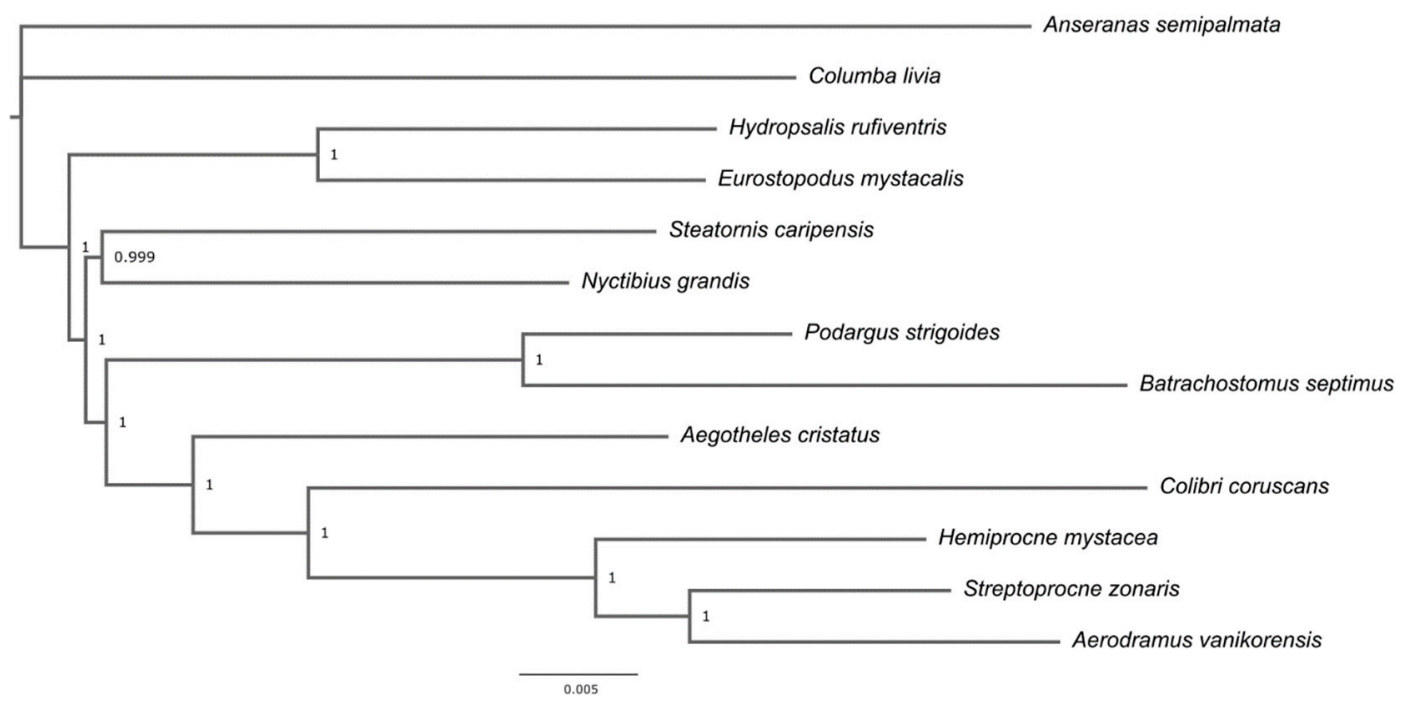

Figure 2. 50\% majority-rule tree resulting from Analysis 1 (run with only molecular data). Numbers on nodes represent Bayesian posterior probabilities.

With the exception of the aforementioned non-monophyly of Apodi (see Analyses 1-3 above), the results of Analysis 2 (the independent morphological analysis, Figure 3) were largely congruent with those of Ksepka et al. [8], though the relationships among some taxa were relatively poorly resolved compared to the results of Ksepka et al.'s parsimony-based analysis, which is typical of Bayesian phylogenetic analyses of morphological data [74]. Hassiavis (the only fossil taxon not included in the analysis of Ksepka et al.) was resolved as a daedalornithean in a polytomy with Aegotheles and Apodiformes. Constraining Apodi to be monophyletic (Analysis 3) resulted in Parargornis and Argornis being recovered as stem-trochilids instead of stem-apodiforms, in agreement with the findings of Ksepka et al. (Figure 4). The relationships among taxa outside of Apodiformes remained unchanged. 


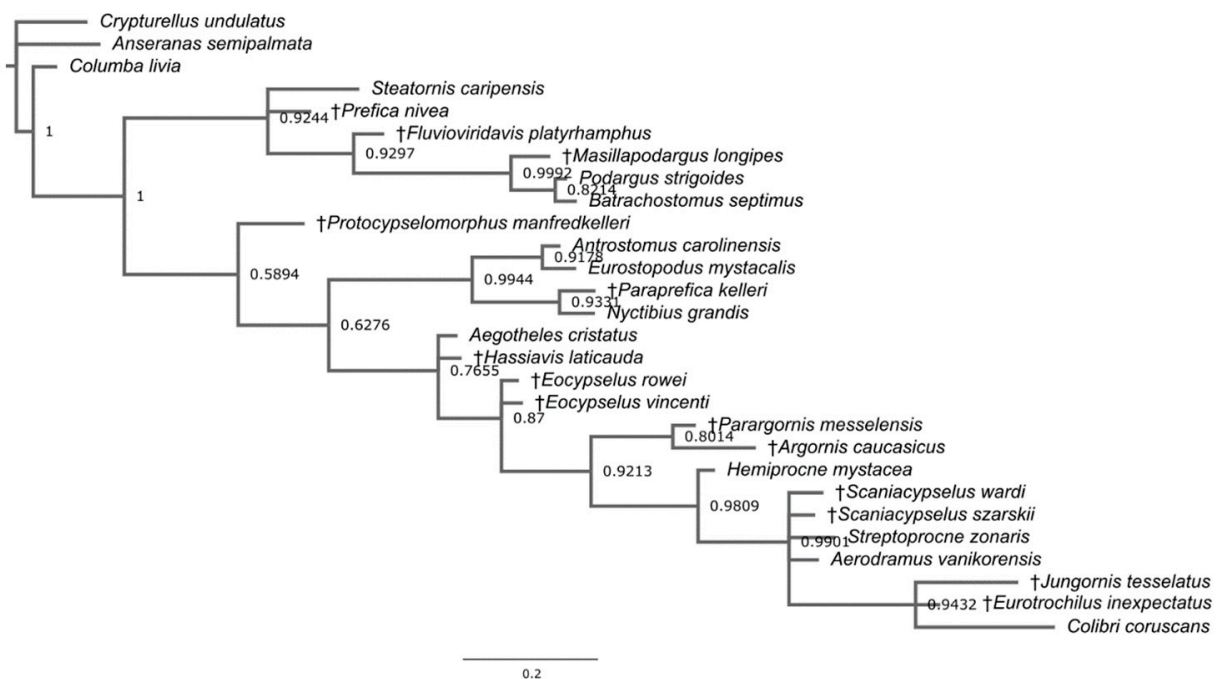

Figure 3. 50\% majority-rule tree resulting from Analysis 2 (run with only morphological data). Numbers on nodes represent Bayesian posterior probabilities. Dagger $(+)$ indicates extinct taxa.

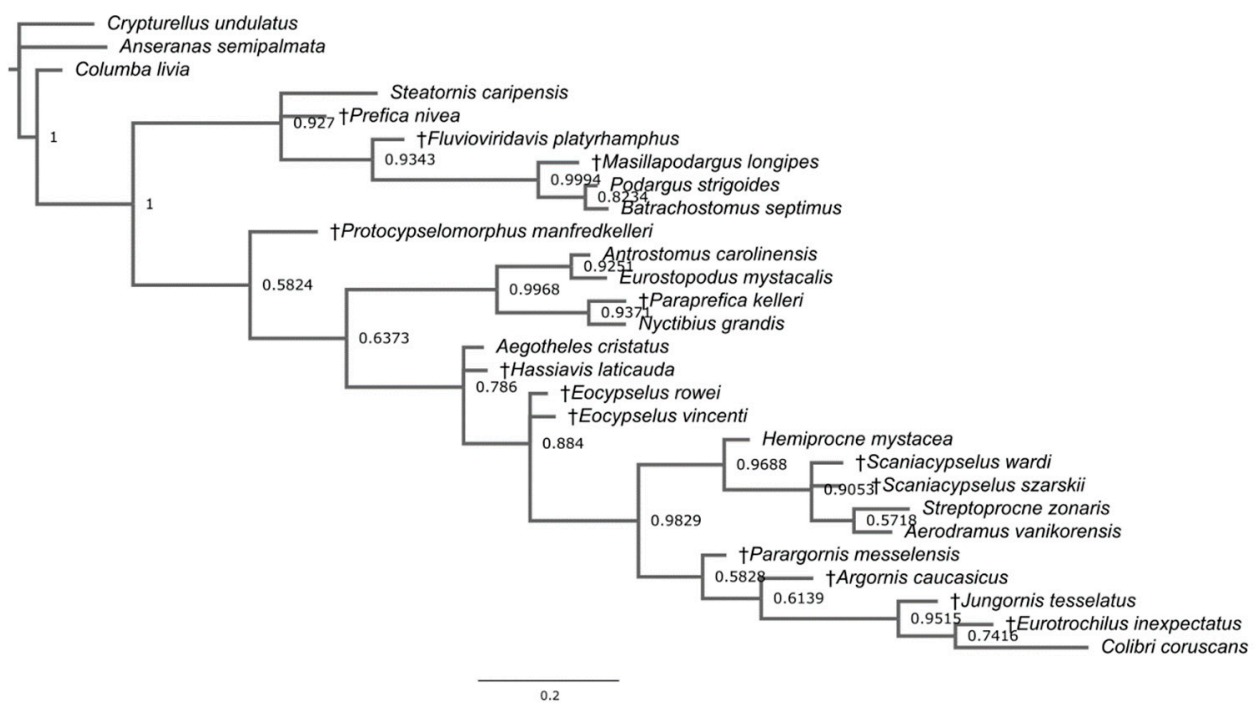

Figure 4. 50\% majority-rule tree resulting from Analysis 3 (run with only morphological data, with Apodi constrained to be monophyletic). Numbers on nodes represent Bayesian posterior probabilities. Dagger $(\dagger)$ indicates extinct taxa.

The total-evidence analysis combining the molecular and morphological datasets (Analysis 4) indicated relationships among extant strisoreans identical to the results of our molecular-only analysis (Figure 5). Despite this, some of the major splits within Strisores had much lower statistical support values than in the molecular-only analysis, with the clades (Steatornithidae + Nyctibiidae) and (Podargidae + Daedalornithes) supported by PP $\leq 0.60$. 


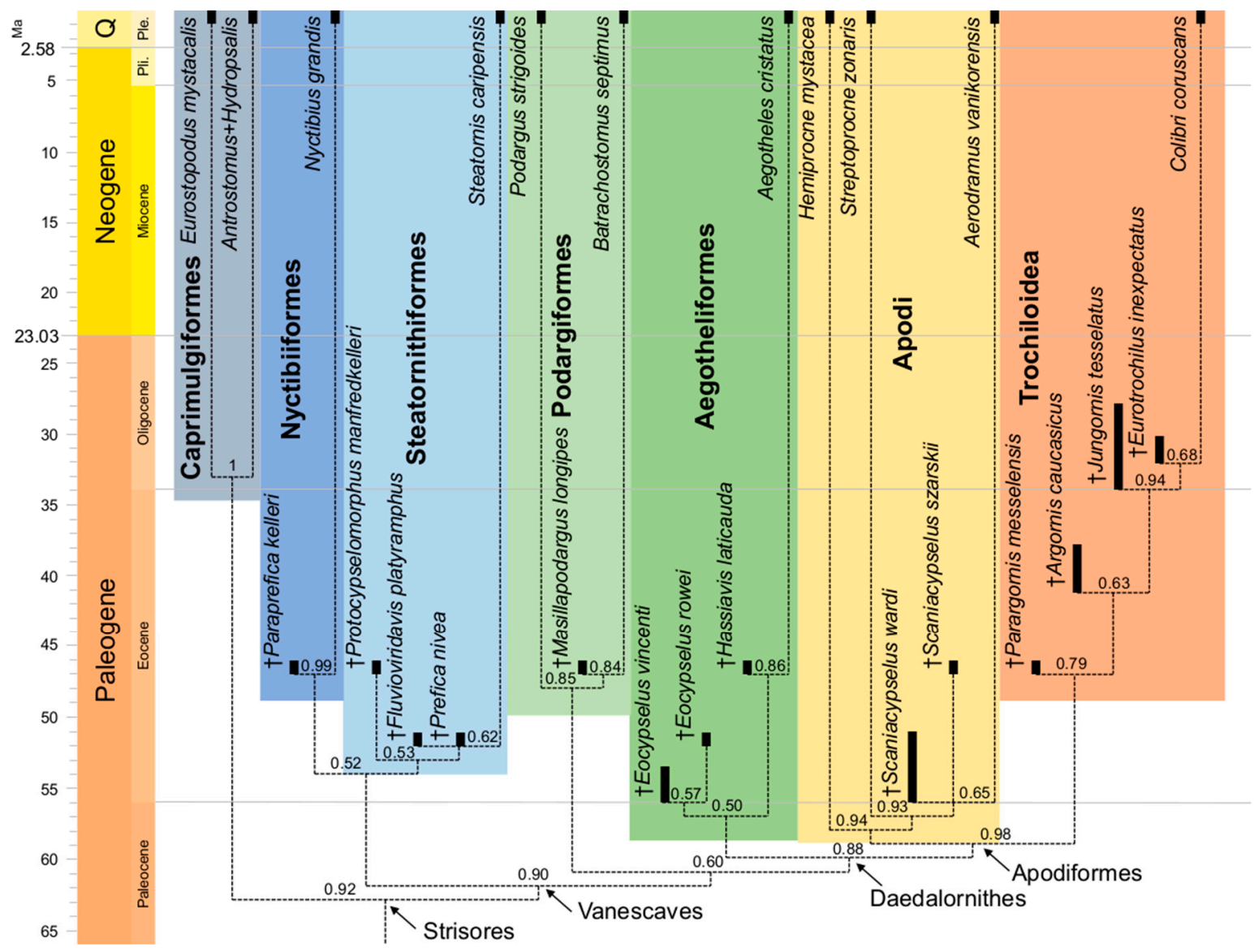

Figure 5. 50\% majority-rule tree resulting from Analysis 4 (run with combined morphological and molecular data) scaled to geologic time. For MrBayes output tree showing inferred branch lengths, see Figure S1. Dagger $(\dagger)$ indicates extinct taxa. Age ranges for fossil taxa include stratigraphic uncertainty and are based on Mayr [30,39] and Ksepka and Clarke [54]. Timing of divergence between Eurostopodus and other caprimulgids is based on Prum et al. [3]. The ages of other divergences represent minimum estimates constrained by the ages of fossil taxa, though a Paleocene origin of crown-Strisores has been favored by several recent studies $[3,44,75]$. Numbers on nodes represent Bayesian posterior probabilities.

Fossil taxa were largely recovered in positions congruent with those found by the morphology-only analysis. Differences from the morphology-only results include Masillapodargus being recovered as a crown-podargid $(\mathrm{PP}=0.84)$, Protocypselomorphus and Fluvioviridavis as total-group steatornithiforms ( $\mathrm{PP}=0.53$ and 0.62 respectively), the two species of Eocypselus as stem-aegothelids ( $\mathrm{PP}=0.50)$, and the two species of Scaniacypselus as crown-apodids $(\mathrm{PP}=0.59)$. Hassiavis was resolved as a stem-aegothelid with high support $(\mathrm{PP}=0.86)$.

Surprisingly, the topology recovered by analysing the morphological data under a molecular scaffold (Analysis 5, Figure 6) was not identical to the results of simultaneously analysing the molecular and morphological partitions. Under a molecular scaffold, Masillapodargus, Hassiavis, Eocypselus, and Scaniacypselus were instead recovered in positions more congruent with the findings of the morphology-only analysis. However, the results of Analysis 5 were similar to those of the combined molecular-morphological analysis in recovering Protocypselomorphus and Fluvioviridavis as total-group steatornithiforms $(\mathrm{PP}=0.68$ and 0.61 respectively). 


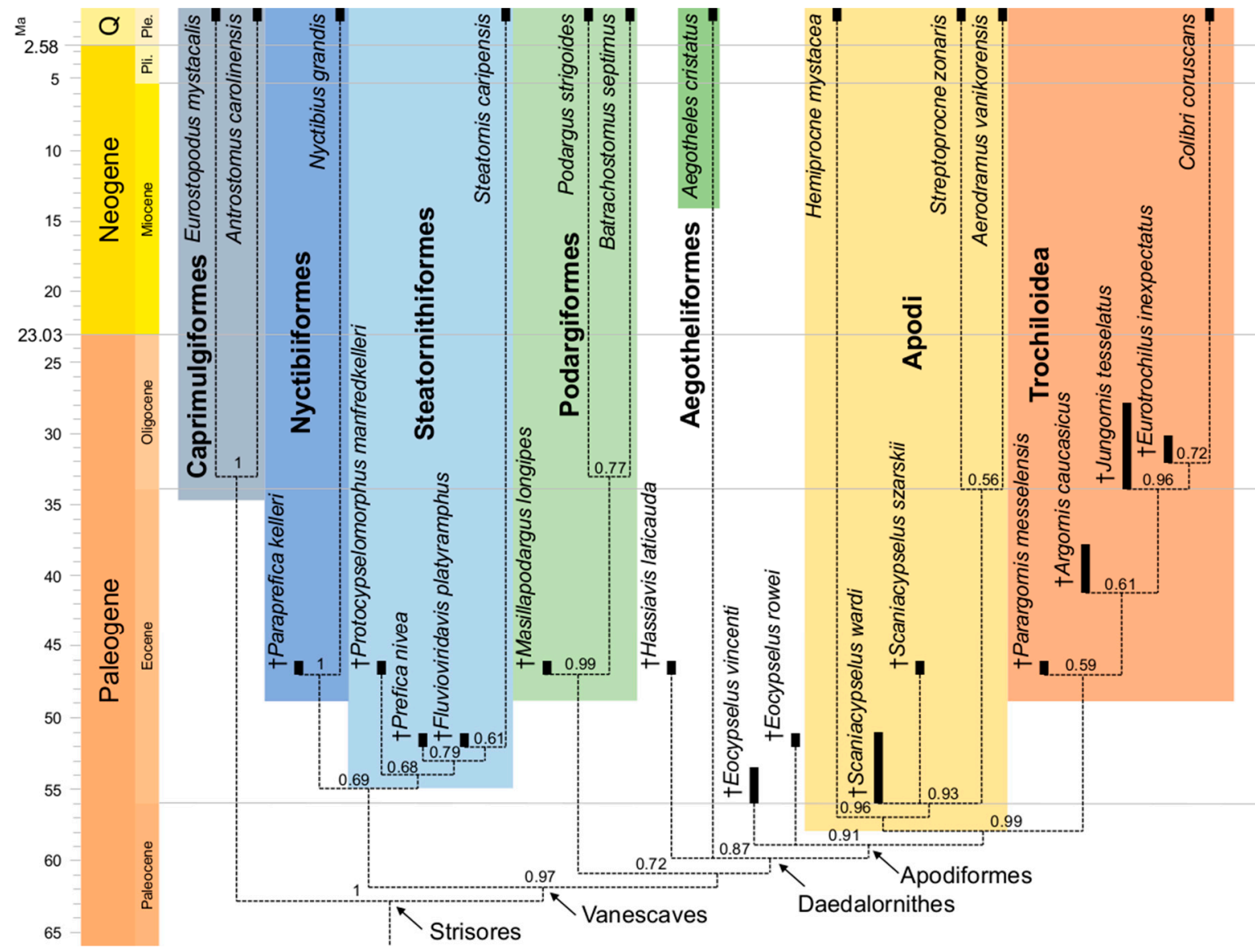

Figure 6. 50\% majority-rule tree resulting from Analysis 5 (run with only morphological data, with relationships of all extant taxa constrained by a molecular scaffold) scaled to geologic time. For MrBayes output tree showing inferred branch lengths, see Figure S2. Dagger ( + ) indicates extinct taxa. Age ranges for fossil taxa include stratigraphic uncertainty and are based on Mayr [30,39] and Ksepka and Clarke [54]. Timing of divergence between Eurostopodus and Antrostomus and between Streptoprocne and Aerodramus are based on Prum et al. [3]. Timing of divergence between Podargus and Batrachostomus has not been estimated by any recent study and was arbitrarily chosen for this figure. The ages of other divergences represent minimum estimates constrained by the ages of fossil taxa, though a Paleocene origin of crown-Strisores has been favored by several recent studies $[3,44,75]$. Numbers on nodes represent Bayesian posterior probabilities.

\subsection{Morphological Synapomorphies}

We mapped the distribution of morphological characters onto the topologies recovered by our total-evidence analyses and identified potential morphological synapomorphies for each node. Herein, synapomorphies are only listed for nodes particularly relevant or novel to this study. Clades that were only recovered by Analysis 4 are marked by *, whereas clades that were only recovered by Analysis 5 are marked by ${ }^{* *}$. Note that one putative morphological synapomorphy for Strisores suggested by Mayr [2] (an elongate crus longum of the ulnare) was not accounted for by the character sampling of our morphological dataset. Select osteological character states are illustrated in Appendix B.

Synapomorphies of Strisores (nine characters): Beak shorter than rest of skull and very wide at base, with narial openings large and reaching far into its tip (char. 3: $0>1$, reversed in Fluvioviridavis, Podargidae, and (Eurotrochilus + Colibri)), strongly protruding posterolaterally-directed processes on palatine (char. 14: $0>1$, reversed in Fluvioviridavis, Steatornis, and Colibri), orbital process of quadrate short (char. 26: $0>1$, reversed in Fluvioviridavis and Steatornis), anterior portion of mandibular symphysis distinctly pointed (char. 33: $0>1$, reversed in Masillapodargus and Batrachostomus), 18 
presacral vertebrae (char. 37: $0>1$, reversed in Steatornithiformes), osseous bridge from transverse process to caudal articular process on third cervical vertebra (char. 40: $0>1$, reversed in Aegotheles and Apodi), acrocoracoid process of coracoid unhooked (char. 49: $0>1$, reversed in Daedalornithes), transverse sulcus on humerus very deep, long, and rectangular (char. 56: 0>1, reversed in Podargidae and Colibri), rictal bristles (char. 103: $0>1$, reversed in Nyctibius and Apodiformes).

Synapomorphies of Caprimulgidae (11 characters): Ectethmoid greatly expanded anterolaterally and inflated, with dorsal margin largely fused with frontals (char. 10: $0>2$, also evolved independently in Nyctibius), pars lateralis of palatine extremely anterolaterally expanded (char. 13: $0>1$, also evolved independently in Nyctibiiformes), rostromedial process of palatine long and slender (char. 18: $0>1$, also evolved independently in Daedalornithes), paroccipital process strongly ventrally protruding, pointed, and at or ventral to the level of the articular surface of the quadrate (char. 22: $0>1$, also evolved independently in Nyctibius), cone-like bony protrusion at posterior margin of optic nerve foramen (char. 23: $0>1$, also evolved independently in Nyctibius), jugal arch strongly bowed so that lateral margin of skull is convex (char. 24: $0>1$, also evolved independently in Nyctibiiformes), orbital process of quadrate essentially absent (char. 26: $1>2$, also evolved independently in Nyctibiiformes), olecranon process of ulna constricted and sharp (char. 70: $0>1$, also evolved independently in Apodiformes), manual phalanx II-1 fenestrated (char. 80: 0 >1, also evolved independently in Nyctibius, Prefica, Aegotheles, Hemiprocne, Argornis, and Colibri), pelvis width across antitrochanters greater than length of synsacrum (char. 83: $0>1$, also evolved independently in Steatornis and Daedalornithes), intertarsal sesamoid (char. 89: $0>1$, also evolved independently in Nyctibius and Streptoprocne).

Synapomorphies of Vanescaves, new taxon (Steatornithidae + Nyctibiidae + Podargidae + Daedalornithes) (one character): Descending process of the lacrimal poorly developed or absent (char. 7: $0>1)$.

Synapomorphy of (Steatornithidae + Nyctibiidae) (one character): Unossified pons supratendineus on distal tibiotarsus (char. 87: $0>1$, also evolved independently in Hemiprocne), also share greatly abbreviated tarsometatarsus (char. 90: $0>1$ ) except in Protocypselomorphus.

Synapomorphies of Steatornithiformes (Protocypselomorphus + Fluvioviridavis + Prefica + Steatornis) (three characters): 19 or more presacral vertebrae (char. 37: 1>0), fossa m. brachialis on humerus deep and sharply delimited (char. 61: $1>2$, also evolved independently in Podargidae), tibiotarsus shorter or about equal length to carpometacarpus (char. 86: $0>1$, reversed in Fluvioviridavis).

Synapomorphy of (Fluvioviridavis + Prefica + Steatornis) (one character): Omal tip of furcula lacking distinct, laterally protruding acrocoracoid articular facies (char. 43: $1>0$, also evolved independently in Podargidae and Eocypselus vincenti).

Synapomorphies of (Fluvioviridavis + Steatornis)**: No unambiguous synapomorphies.

Synapomorphies of Nyctibiiformes (Paraprefica + Nyctibius) (five characters): Pars lateralis of palatine extremely anterolaterally expanded (char. 13: $0>1$, also evolved independently in Caprimulgidae), jugal arch strongly bowed so that lateral margin of skull is convex (char. 24: $0>1$, also evolved independently in Caprimulgidae), orbital process of quadrate essentially absent (char. 26: $1>2$, also evolved independently in Caprimulgidae), mandible with intraramal joint and posterior half of mandibular rami greatly widened, as well as dorsally flattened (char. 35: $0>1$, also evolved independently in Caprimulgidae), small proximal end of mandible, with short lateral cotyle and stout medial process of mandible forming narrow sulcus (char. 36: $0>1$, also evolved independently in Caprimulgidae and Aegotheles).

Synapomorphy of (Podargidae + Daedalornithes) (one character): Distal interosseous canal of tarsometatarsus absent (char. 99: $0>1$, also evolved independently in Antrostomus, reversed in Streptoprocne).

Synapomorphies of Podargiformes (Podargus + Masillapodargus + Batrachostomus) (22 characters): Ossified nasal septum (char. 1: $0>1$, also evolved independently in Fluvioviridavis and Steatornis), rim surrounding anterior of external naris extends anterolaterally onto dorsal surface of beak (char. 2: $0>1$, also evolved independently in Fluvioviridavis), beak longer than rest of skull (char. 3: 1>0, also evolved 
independently in Fluvioviridavis and (Eurotrochilus + Colibri)) dense neurovascular pitting on rostrum (char. 4: $0>1$, also evolved independently in Fluvioviridavis and Steatornis), maxilla extends laterally and posteriorly to contact jugal bar (angulus tomialis) (char. 5: $0>1$, also evolved independently in Fluvioviridavis and Steatornis), distinct nasofrontal hinge (char. 6: $0>1$, also evolved independently in Steatornis), greatly enlarged sclerotic ossicles (char. 9: $0>1$, also evolved independently in Nyctibius), postorbital process elongated, touching or nearly touching jugal bar (char. 11: $0>1$ ), internal choanae open posteriorly (char. 16: $0>1$ ), palatine bears a fossa on ventral surface anterior to internal choana and separated from its counterpart by a midline lamina (char. 19: $0>1$ ), temporal fossae of parietal meeting or almost meeting at midline of skull (char. 25: $0>1$, also evolved independently in (Fluvioviridavis + Prefica + Steatornis)), mandibular articulation with quadrate includes a locking mechanism formed by laterally directed peg on quadrate fitting into a medially open concavity of the articular (char. 30: $0>1$ ), posterior edge of articular portion of mandible rounded posteriorly in dorsal view (char. 31: $0>1$, also evolved independently in Fluvioviridavis), ventral margin of mandibular rami virtually straight in lateral view (char. 32: $0>1$, also evolved independently in Fluvioviridavis), pronounced monotonic curvature of mandibular rami producing continuous lateral concavity (char. 34: $0>1$, also evolved independently in Fluvioviridavis), osseous bridge from costal process to midsection of corpus on fifth cervical vertebra (char. 41: $0>1$, also evolved independently in Nyctibius), omal tip of furcula lacking distinct, laterally protruding acrocoracoid articular facies (char. 43: $1>0$, also evolved independently in (Fluvioviridavis + Prefica + Steatornis) and Eocypselus vincenti), transverse sulcus on humerus not very deep, long, and rectangular (char. 56: $1>0$, also evolved independently in Colibri), fossa m. brachialis on humerus deep and sharply delimited (char. 61: 1>2, also evolved independently in Steatornithiformes), distal wing shorter than humerus (char. 72: 1>0, also evolved independently in Paraprefica), cranial face of manual phalanx II-1 dorsoventrally widened (char. 76: $0>1$, also evolved independently in Prefica and Steatornis), two bony canals present in hypotarsus enclosure of tendons of $m$. flexor digitorum longus and $m$. flexor hallucis longus (char. 91: $1>2$, also evolved independently in Nyctibius).

Synapomorphy of (Masillapodargus + Batrachostomus) ${ }^{*}$ (one character): Anterior portion of mandibular symphysis nearly rounded (char. 33: $1>0$ ).

Synapomorphies of (Podargus + Batrachostomus)** (two characters): Horns projecting posteriorly at front of orbit (char. 8: $0>1$ ), palatines fused anterior to internal choanae (char. 17: $0>1$, also evolved independently in Fluvioviridavis and Steatornis).

Synapomorphies of Daedalornithes (11 characters): Rostromedial process of palatine long and slender (char. 18: $0>1$, also evolved independently in Caprimulgidae), many small pneumatic foramina on dorsal margin of posterior surface of the otic process of the quadrate (char. 28: 1>0), transverse foramina on axis absent (char. 39: $0>1$, also evolved independently in Nyctibius), supracoracoid nerve foramen on coracoid (char. 45: $0>1$, also evolved independently in Fluvioviridavis), tip of acrocoracoid process of coracoid hooked (char. 49: 1>0), pelvis width across antitrochanters greater than the length of the synsacrum (char. 83: $0>1$ ), terminal portion of ischium slender, creating wide ischiopubic fenestra (char. 85: $0>1$ ), cerebellum with reduced anterior lobe and relatively large posterior lobe (char 101: $0>1$, also evolved independently in Caprimulgidae), caecum absent (char. 102: $0>1$ ), m. splenius capitis with cruciform origin (char. 107: $0>1$ ), m. fibularis longus absent (char. 112: $0>1$, also evolved independently in Steatornis).

Synapomorphies of Aegotheliformes (Eocypselus + Hassiavis + Aegotheles)* ${ }^{*}$ No unambiguous synapomorphies.

Synapomorphies of (Hassiavis + Aegotheles)*: No unambiguous synapomorphies, but share bifurcated external spine of sternum (char. 52: $0>1$, ambiguous because the state of this character is unknown in Eocypselus).

Synapomorphies of (Eocypselus + crown-Apodiformes) ${ }^{* *}$ (three characters): Abbreviated humerus with ratio of length to midshaft less than 10 (char. 54: $0>1$ ), caudal prominence of ventral tubercle on 
humerus distinctly greater than that of humeral head (char. 57: $0>1$, also evolved independently in Caprimulgidae and Nyctibius), arcus extensorius of tarsometatarsus present (char. 92: $0>1$ ).

Synapomorphy of (Scaniacypselus + Aerodramus)* (one character): Attachment of $m$. tensor propatagialis pars brevis at the proximally displaced dorsal supracondylar process of humerus (char. 64: 1 > 2).

Synapomorphies of (Streptoprocne + Aerodramus)** (three characters): Fossa m. brachialis on humerus absent (char. 61: $1>0$, also evolved independently in (Jungornis + Colibri)), olecranon process on ulna constricted and sharp (char. 70: $0>1$, also evolved independently in Caprimulgidae and Trochiloidea), second and third phalanges of pedal digit IV greatly abbreviated (char. 100: $0>1$, also evolved independently in Steatornis and Colibri).

\section{Discussion}

\subsection{Conflict Between Molecular and Morphological Data}

This report represents one of the few studies that has used a total-evidence approach to evaluate the contentious phylogenetic relationships among Strisores, and is by far the most comprehensive study to have done so. Our molecular-only and total-evidence results recover a general topology in which Caprimulgidae, (Steatornithithdae + Nyctibiidae), and Podargidae are successively more closely related to Daedalornithes. Notably, the statistical support for a (Steatornithidae + Nyctibiidae + Podargidae + Daedalornithes) clade excluding Caprimulgidae was high in both our molecular and total-evidence topologies ( $P P \geq 0.90$ ). In recognition of the robust support for this previously unnamed group, we coin the new name, Vanescaves, for this clade (see Appendix A for etymology and phylogenetic definition). These results are congruent with those of two recent studies that employed purely phylogenomic approaches $[3,10]$.

We found that the simultaneous analysis of molecular and morphological data did not increase confidence in any specific phylogenetic topology. In fact, the addition of morphological data greatly reduced statistical support for several of the deepest nodes in strisorean phylogeny. This suggests high conflict in phylogenetic signal between our molecular and morphological datasets, which is also evidenced by the contrasting topologies found by our morphology-only and molecular-only analyses. However, this should not be taken as an indictment of a total-evidence phylogenetic approach: morphology remains the only source of data with which most fossil taxa can be placed into phylogenetic context, and a total-evidence approach has been used to effectively resolve the affinities of fossil taxa that have been the subject of longstanding phylogenetic controversies (e.g.: $[18,19])$. Several factors likely contributed to the reduced statistical support for the results of our combined molecular-morphological analysis:

Firstly, evidence from both fossils (e.g.: [76]) and molecular divergence time estimates (e.g.: $[3,44,75,77,78])$ indicate that many deep divergences within Neoaves occurred at least as early as the Paleocene. Thus, it may be that members of major strisorean subgroups had already acquired their distinctive morphologies by the Eocene, obscuring their ancestral character states and hampering congruence between morphology- and molecule-derived phylogenies despite their rich fossil record. This is supported by the fact that five or more morphological synapomorphies could be identified for Nyctibiiformes and Podargiformes in the present study, whereas the deeper divergences between these groups could only be characterized by 1-2 morphological features, most of which have experienced secondary reversals in at least one constituent species. Mayr [2] previously noted that few osteological similarities are shared between Steatornithidae and Nyctibiidae, despite recent molecular analyses suggesting a close relationship between these two groups. In some cases, such as the absence of the distal interosseous canal of the tarsometatarsus (the sole morphological synapomorphy identified for a (Podargidae + Daedalornithes) clade), potential synapomorphies characterizing deep divergences in Strisores are also widespread among other crown-birds [2,79] and cannot be considered uniquely diagnostic of the clades recovered by our analyses. Furthermore, some synapomorphies of Strisores 
identified by our and previous studies (such as the very short bill and the deep transverse sulcus of the humerus) [80,81] are not present in podargids, as previously pointed out by Mayr [4]. Thus, in contrast to our expectation that Strisores represents a clade for which morphological data may be critical for resolving interrelationships of extant taxa [2,36], increased congruence between studies of strisorean phylogeny may instead depend on further refinement of phylogenomic approaches and the discovery of even older fossils that better elucidate the ancestral characteristics of Strisores and its major constituent subclades.

A second potential barrier to resolution in our combined molecular-morphological analysis is the relatively small size of our morphological dataset. Though very large morphological matrices for crown-birds have been criticized on the grounds that they may contain proportionately little phylogenetic signal [82], it is clear that the present dataset does not incorporate all potentially relevant morphological characters (e.g.: the aforementioned exclusion of the length of the crus longum of the ulnare as a character in our matrix). Our dataset also lacks coverage of certain skeletal elements such as the scapula, femur, and caudal vertebrae. The assembly of large datasets becomes a necessity with increased phylogenetic scope and availability of morphological information [83], thus, expanded morphological datasets may in the future assist with the resolution of strisorean phylogeny.

\subsection{Effects of Alternative Total-Evidence Approaches}

It is not obvious why the positions of some fossil taxa were recovered differently by analyses that used alternative methods of integrating molecular and morphological data. For Eocypselus, the statistical support for a stem-apodiform position $(\mathrm{PP}=0.91$, as recovered under molecular scaffolding) was markedly higher than that for a stem-aegothelid position ( $\mathrm{PP}=0.50$, as recovered under the simultaneous analysis of molecules and morphology). In the case of Masillapodargus and Scaniacypselus, neither of the alternative placements for these taxa indicated by the two total-evidence analyses had obviously superior statistical support. However, the phylogenetic positions for these taxa found under molecular scaffolding were generally more congruent with the conclusions of previous studies $[8,36,37,39]$, and tended to be characterized by greater numbers of unambiguous morphological synapomorphies compared to the results of the simultaneous combined analysis. We are, therefore, hesitant to accept the novel placements recovered for Masillapodargus, Eocypselus, and Scaniacypselus recovered by the combined molecular-morphological analysis. Pending more detailed assessment of the morphology and affinities of these fossil taxa, we strongly advise against the use of Masillapodargus, Eocypselus, and Scaniacypselus as fossil calibrations for crown-Podargidae, Aegotheliformes, and crown-Apodidae respectively in divergence time studies. Evaluating the relative accuracy of simultaneous combined analyses versus molecular scaffolding is beyond the scope of this study. However, our results indicate that these two methods can produce differing results when data are analysed under a Bayesian framework, even when the molecular dataset used for combined analysis greatly exceeds the morphological dataset in character count. This finding is notable because previous studies employing total-evidence phylogenetics have generally opted for applying only one of these two approaches, and it has been suggested that both methods would likely recover the same topology in cases where the molecular dataset is much larger than the morphological dataset [29]. We suggest that the use of both approaches on the same datasets can highlight previously unappreciated ambiguity in the phylogenetic placement of fossil taxa, and we also encourage future studies that aim to clarify the methodological mechanisms that may underlie these discrepancies.

\subsection{Affinities of Hassiavis}

The recovery of Hassiavis as a stem-aegothelid in the combined molecular-morphological analysis had relatively strong statistical support and is at least compatible with the results of molecular scaffolding (which found it in a polytomy with Aegotheles and total-group Apodiformes). The presence of a hooked acrocoracoid process on the coracoid in Hassiavis is suggestive of daedalornithean affinities. Within Daedalornithes, it shares only one notable character with Aegotheles (a bifurcated external 
spine of the sternum), but this feature is not found in any other daedalornithean included in our study (and is only present in Eurostopodus among non-daedalornitheans). Cranial similarities between Hassiavis and aegothelids were previously noted by Mayr [53], though he also considered it possible that these represented plesiomorphic features. Prior to the present study, the next oldest fossil taxa that had been assigned to Aegotheliformes were Quipollornis koniberi from the early to middle Miocene of Australia [84], and a tarsometatarsus referred to Aegotheles sp. from the early to middle Miocene of New Zealand [85]. Thus, if the aegotheliform affinities of Hassiavis are upheld by future studies, it would represent the first recognized example of a Paleogene stem-aegothelid and extend the known temporal range of total-group Aegotheliformes by at least 23 million years. In addition, Hassiavis would be the first aegotheliform identified outside of the Australasian region and would, thereby, provide an additional example of a previously widespread avian clade currently restricted to Gondwanan vestiges [30,86-91].

Mayr [52] considered Hassiavis to be a close relative of Archaeotrogon, which is represented by four species from the Eocene-Oligocene of France [92]. Although fossils of Archaeotrogon are abundant, we excluded it from our dataset because these specimens consist largely of isolated limb elements [92]. In addition, our character sampling did not include most of the proposed synapomorphies of a (Hassiavis + Archaeotrogon) clade identified by Mayr (e.g.: large humeral head, ventrally displaced attachment site of the $m$. scapulohumeralis caudalis on humerus, large distal vascular foramen on tarsometatarsus set in a groove). As a result, the present study does not permit a rigorous reassessment of the affinities of Archaeotrogon. However (as already noted by Mayr [52]), Hassiavis differs greatly from Archaeotrogon in coracoid morphology. Notably, Archaeotrogon lacks a hooked acrocoracoid process of the coracoid, which was optimized as a synapomorphy of Daedalornithes in the present study and found in no other strisoreans included in our dataset. This may suggest that Archaeotrogon was a non-daedalornithean strisorean not closely related to Hassiavis. Alternatively, Archaeotrogon may be a close relative of Hassiavis within Daedalornithes that secondarily lost the hooked acrocoracoid process. A third possibility is that both genera are non-daedalornithean strisoreans, but this is not supported by the present study, at least with respect to Hassiavis.

\subsection{Affinities of Fluvioviridavis}

One fossil strisorean whose phylogenetic position has been particularly contentious is Fluvioviridavis. The holotype of Fluvioviridavis was originally referred to Prefica by Olson [32] before being named and described as a new genus and species by Mayr and Daniels [56], who considered its phylogenetic affinities uncertain, though they acknowledged that it had similarities to some strisorean taxa such as Steatornis. Mayr [30] tentatively assigned it to Strisores based on the overall morphology of its skull and hindlimbs. Nesbitt et al. [36] later described a second specimen of Fluvioviridavis and ran a phylogenetic analysis that recovered it as a stem-podargid, a conclusion also supported by the phylogenetic analysis of Ksepka et al. [8]. However, Mayr [37] expressed scepticism of podargiform affinities for Fluvioviridavis, noting that its humerus and coracoid morphology is more similar to that of Steatornis. Mayr instead suggested that Fluvioviridavis was an early-diverging strisorean excluded from a clade including all non-steatornithiform strisoreans (Podargocypseli), a grouping not supported by the present study. Mayr also pointed out that Fluvioviridavis differs from all extant strisoreans besides Steatornis in the unreduced orbital process of the quadrate, the absence of an angulus caudolateralis of the palatine, and the possession of 19 presacral vertebrae (instead of fewer). It is, therefore, noteworthy that both of our total-evidence analyses recovered Fluvioviridavis as a steatornithiform instead of a podargiform. This result was retrieved in spite of the fact that not all of the relevant morphological features discussed by Mayr (e.g.: the angle of the scapula corpus, the length of the hallux, and the width of the sternal end of the coracoid) were taken into account by our morphological dataset. However, we nonetheless found that nearly all of the features optimized as synapomorphies for Podargiformes were also present in Fluvioviridavis, suggesting a high degree of morphological similarity, and indeed our morphology-only analysis continued to recover Fluvioviridavis as a stem-podargid with high 
statistical support. Similarly, some of the features shared between Fluvioviridavis and Steatornis are also present in podargids, and others (such as presacral vertebrae count) are known to be plesiomorphic for Neoaves [2]. As such, neither podargiform nor steatornithiform affinities for Fluvioviridavis can be conclusively rejected by our study. The genus Palaeopsittacus from the Eocene of England and Germany has been noted as sharing anatomical similarities with Fluvioviridavis [30,93], and may represent another stem-podargid or stem-steatornithid. Palaeopsittacus was not included in the present study because its potential strisorean affinities have yet to be rigorously established, but an assessment of its phylogenetic position using analyses that include a broader taxonomic sample of crown-group birds would be worthy of consideration in future studies.

\subsection{Morphological Evolution of Strisoreans}

Our total-evidence analyses indicate that a high level of morphological homoplasy characterizes the deep strisorean subclades, which likely contributes to the pronounced discrepancies between our morphological and molecular topologies. For example, we identified many homoplastic features shared between Steatornis and podargids (e.g.: the ossified nasal septum, distinct nasofrontal hinge, and temporal fossae that almost meet at the midline of the skull). Steatornis and Podargidae have previously been suggested to be extant sister taxa by some morphological analyses (e.g.: [8]). Morphological analyses also tend to find a strongly-supported sister group relationship between caprimulgids and nyctibiids, a relationship that has not been recovered by any molecular studies to date. Our results suggest that at least some of the shared features between caprimulgids and nyctibiids (e.g.: the anterolaterally expanded pars lateralis of the palatine, bowed jugal arch, and absence of the orbital process of the quadrate) are either plesiomorphic for Strisores or convergent between the two groups. Caprimulgids and nyctibiids are also the only two strisorean groups known to have a tapetum lucidum, a reflective structure behind the retina that increases light sensitivity in many nocturnal vertebrates $[2,6,82]$, which raises the possibility that the presence of this feature is also either homoplastic or plesiomorphic in strisoreans. The tapetum lucidum is absent in Steatornis [94,95] and undocumented in podargids and aegothelids. If it represents a plesiomorphic trait, its seeming absence in several nocturnal strisorean clades is difficult to explain, which may, in turn, imply multiple origins of nocturnality or crepuscularity in Strisores. Nonetheless, the evolution of nocturnality in strisoreans remains hard to elucidate without a more detailed understanding of adaptations for dark-activity in podargids, aegothelids, and potentially the stem-group representatives of major strisorean clades.

Morphological similarities have additionally been identified among caprimulgids, nyctibiids, and daedalornitheans, resulting in the name Cypselomorphae being applied to a putative clade uniting these groups to the exclusion of Steatornithidae and Podargidae [2,55]. Such an assemblage has also not been recovered by any molecular analyses, which instead nest steatornithids and podargids among cypselomorph taxa. It is not implausible that steatornithids and podargids represent morphologically aberrant clades that have been highly modified from their ancestral states, given that both groups employ foraging strategies distinct from the aerial flycatching behaviour practiced by most strisoreans. Steatornis is unusual among strisoreans in being frugivorous [47,96], and adaptations for frugivory have been identified in the stem-steatornithid Prefica [32]. The hunting behaviour of podargids in the wild is poorly studied, but limited observations suggest that at least Podargus typically captures prey on the ground or tree trunks instead of in the air $[47,97]$. The distinctive beak morphology of podargids (e.g.: being longer relative to the rest of the skull compared to that of other strisoreans, having internal choanae that open posteriorly, a locking mechanism at the mandibular articulation with the quadrate, and straight ventral margins of the mandibular rami), which may be an adaptation to this feeding method, is at least incipiently present in the Eocene podargiform Masillapodargus as well as the putative podargiform Fluvioviridavis [36]. Considering that Prefica and Masillapodargus already possessed at least some ecological specializations of their apparent closest extant relatives, it may be that they did not retain many strisorean symplesiomorphies. This possibility would be consistent with the fact that many features suggested to be synapomorphies of morphology-based strisorean clades are cranial 
characters, and thus are potentially correlated with feeding behaviour. An evolutionary scenario in which podargids descended from aerial foragers was previously postulated by Serventy [97] based on comparative skull morphology among extant strisoreans.

It is notable that both of our total-evidence analyses recovered the Eocene strisorean Protocypselomorphus as an early-diverging steatornithiform, whereas it is generally recovered as a stem-cypselomorph by our and previous morphological phylogenetic studies [8,55]. Statistical support for steatornithiform affinities in our total-evidence analysis is low, but Protocypselomorphus does share some notable similarities with Steatornis (such as the presence of 19 or more presacral vertebrae and the proportions of the tibiotarsus relative to the carpometacarpus) and Mayr [30] previously noted that its overall morphology agrees with Steatornithidae. If Protocypselomorphus was indeed a stem-steatornithid that retained a highly plesiomorphic morphology, that would be consistent with the possibility that the similarities among cypselomorphs, in fact, represent ancestral characters of Strisores.

\section{Conclusions}

The present work represents one of the most comprehensive studies on strisorean phylogeny to date in terms of character sampling, combining a genome-scale molecular dataset and a large sample of fossil taxa in an attempt to resolve the internal relationships of this enigmatic clade of birds. The preferred topology found in this study places Caprimulgidae, (Steatornithidae + Nyctibiidae), and Podargidae as successively closer relatives of Daedalornithes, which is congruent with the results of some other recent phylogenomic analyses of Strisores. We also identified possible morphological synapomorphies that unite strisorean clades recovered using molecular data and potential fossil evidence that may support aerial foraging as the ancestral ecology of Strisores, as implied by molecular topologies. Contrary to expectations, however, combining morphological and molecular datasets did not increase confidence in any specific phylogenetic topology, despite the inclusion of a phylogenetically diverse range of well-known fossil taxa. We attribute this surprising result to high levels of morphological homoplasy in Strisores, early morphological diversification possibly obscuring ancestral morphologies in known fossil strisoreans, and the relatively small size of existing morphological matrices pertaining to strisoreans. Further refinement of phylogenomic methods may also advance future estimates of strisorean phylogeny. Our findings suggest that improved understanding of morphological evolution in strisoreans will be contingent on the discovery of even older fossil taxa that retain more plesiomorphic morphologies, as well as more comprehensive character sampling in morphological datasets.

Supplementary Materials: The following are available online at http://www.mdpi.com/1424-2818/11/9/143/s1, Text: Chen_Strisores_SupplementaryText.docx, Figure S1: Chen_Strisores_FigureS1.png, Figure S2: Chen_Strisores_FigureS2. png. Data matrices used in this study are available on Zenodo (http://doi.org/10.5281/zenodo.3351601). CT volume files and mesh files for segmented models of examined specimens have been uploaded to MorphoSource (project No. 820).

Author Contributions: Conceptualization, A.C. and D.J.F.; methodology, A.C. and D.J.F.; software, A.C.; validation, A.C.; formal analysis, A.C.; investigation, all authors; resources, all authors; data curation, A.C. and R.B.J.B.; writing - original draft preparation, A.C.; writing - review and editing, all authors; visualization, A.C. and R.B.J.B.; supervision, D.J.F. and A.C.; project administration, D.J.F. and A.C.; funding acquisition, all authors.

Funding: Parts of this project were supported by Systematics Research Fund awards to A.C. and D.J.F. by the Linnean Society of London and the Systematics Association. D.J.F. also acknowledges support from the Isaac Newton Trust early career support scheme. Parts of this project were also funded by the European Union's Horizon 2020 research and innovation program 2014-2018 under grant agreement 677774 (European Research Council [ERC] Starting Grant: TEMPO) to R.B.J.B. N.D.W. and M.J.B. received Smithsonian Institution support through the Predoctoral Fellowship Program (N.D.W.), the Frontiers in Phylogenetics Program, the Scholarly Studies Program, and the Consortium for Understanding and Sustaining a Biodiverse Planet.

Acknowledgments: We would like to thank Moritz Dukatz for translating the German description of Hassiavis, Mark Puttick for technical assistance with the use of MrBayes, Mark Miller for the allocation of additional usage hours on CIPRES, Ben Creisler for advice on formulating the name "Vanescaves", and Gerald Mayr and Jerry Harris for sharing information on specimens of Scaniacypselus. We are grateful to Dan Ksepka for providing extensive helpful feedback and discussion that significantly improved previous drafts of this paper. This manuscript also benefited from the comments of two anonymous reviewers. We additionally thank Tom Davies (University of Bristol), April Neander and Zhe-Xi Luo (University of Chicago), and Matt Friedman (University of Michigan) for access to, and technical support during, CT scanning. This study includes data produced in the CTEES facility at 
University of Michigan, supported by the Department of Earth \& Environmental Sciences and College of Literature, Science, and the Arts, at the Chicago paleoCT facility, and the X-ray Tomography Facility at the University of Bristol. Ben Marks (Field Museum of Natural History, Chicago), Judith White and Jo Cooper (Natural History Museum bird collection, Tring), and Janet Hinshaw (University of Michigan Museum of Zoology) facilitated access to specimens. Alex Bjarnason, Andrew Orkney and Stephanie Wright provided assistance with processing CT datasets. This manuscript was written in memory of James $\mathrm{O}^{\prime} \mathrm{Shea}$, a kind and brilliant colleague who tragically passed away during the preparation of this study.

Conflicts of Interest: The authors declare no conflict of interest. The funders had no role in the design of the study; in the collection, analyses, or interpretation of data; in the writing of the manuscript, or in the decision to publish the results.

\section{Appendix A}

Table A1. This appendix lists higher-order taxon names that have been applied to Strisores and proposed phylogenetic definitions. All definitions are newly proposed by this study unless otherwise stated.

\begin{tabular}{cc}
\hline Taxon & Phylogenetic Definition \\
\hline & The most inclusive clade including Caprimulgus europaeus, Steatornis \\
caripensis, Nyctibius grandis, Podargus strigoides, Aegotheles cristatus, and \\
Apus apus but not Phoenicopterus ruber, Columba oenas, Otis tarda, \\
Musophaga violacea, Opisthocomus hoazin, Grus grus, Charadrius hiaticula, \\
Phaethon aethereus, Procellaria aequinoctialis, or Vultur gryphus
\end{tabular}

Notes: Although Mayr [2] had already recruited the name Strisores for this grouping, Cracraft [98] coined Caprimulgimorphae to provide a name with a suitable suffix for a superordinal clade. (Caprimulgiformes sensu lato, as used by alternative taxonomic schemes such as del Hoyo et al. [47] and Gill and Donsker [99], also corresponds to this clade. A less inclusive concept of Caprimulgiformes, as adopted here, has been used by others such as

Chesser et al. [100] and Piacentini et al. [101].) Given that Mayr was the first to explicitly propose a name for this clade based on rigorous phylogenetic analysis, we favour the use of Strisores here. However, our proposed phylogenetic taxonomy assigns slightly different definitions to each name, allowing both to remain in use while preserving their intended taxonomic content. We suggest a branch-based definition for Caprimulgimorphae, following precedent set by most previous defined clades that contain the suffix "-morpha", including those that encompass parts of the avian stem-group, such as Maniraptoromorpha [102] and Dinosauromorpha [103]. As defined here, Caprimulgimorphae corresponds to the total group of Strisores and would therefore also include stem-strisoreans should any be identified in future studies. The precise interrelationships of neoavian birds remain unsettled, thus the external specifiers here include representatives from all major groups consistently recovered as monophyletic by recent studies [3,44,75]: Mirandornithes (Phoenicopterus ruber), Columbimorphae (Columba oenas), Otidimorphae (Otis tarda and Musophaga violacea), Opisthocomiformes (Opisthocomus hoazin), Gruiformes (Grus grus), Charadriiformes (Charadrius hiaticula), Phaethontimorphae (Phaethon aethereus), Aequornithes (Procellaria aequinoctialis), and Telluraves (Vultur gryphus).

Strisores Baird, 1858 [104]

The least inclusive clade including Caprimulgus europaeus, Steatornis caripensis, Nyctibius grandis, Podargus strigoides, Aegotheles cristatus, and Apus apus

Notes: See notes for Caprimulgimorphae. As defined here, Strisores is a crown group that includes the last common ancestor of extant strisoreans and its descendants.

Podargocypseli Mayr, 2010 [2]

The most inclusive clade including Caprimulgus europaeus, Nyctibius grandis, Podargus strigoides, Aegotheles cristatus, and Apus apus but not Steatornis caripensis

Notes: Mayr [2] coined this name in accordance with a specific phylogenetic hypothesis, that podargids, caprimulgids, nyctibiids, and daedalornitheans form a clade exclusive of steatornithids. As such, our proposed definition reflects this specific topology. Under studies that do not recover this grouping as a clade (such as the present study), this name would not be formally recognized.

Cypselomorphae Huxley, 1867 [105]

The most inclusive clade including Caprimulgus europaeus, Nyctibius grandis, Aegotheles cristatus, and Apus apus but not Steatornis caripensis or Podargus strigoides

Notes: Mayr [53] recruited this name in accordance with a specific phylogenetic hypothesis, that caprimulgids, nyctibiids, and daedalornitheans form a clade exclusive of podargids and steatornithids. As such, our proposed definition reflects this specific topology. The present study does not recover this grouping as a clade. 
Table A1. Cont.

\begin{tabular}{|c|c|}
\hline Taxon & Phylogenetic Definition \\
\hline \multicolumn{2}{|c|}{$\begin{array}{l}\text { Notes: Mayr [2] recruited this name in accordance with a specific phylogenetic hypothesis, that caprimulgids and } \\
\text { nyctibiids form a clade exclusive of other strisoreans. As such, our proposed definition reflects this specific topology. } \\
\text { The present study does not recover this grouping as a clade. }\end{array}$} \\
\hline Caprimulgiformes Ridgway, 1881 [106] & $\begin{array}{l}\text { The most inclusive clade including Caprimulgus europaeus but not } \\
\text { Steatornis caripensis, Nyctibius grandis, Podargus strigoides, Aegotheles } \\
\text { cristatus, or Apus apus }\end{array}$ \\
\hline \multicolumn{2}{|c|}{$\begin{array}{l}\text { Notes: Under the phylogenetic taxonomy proposed here, ordinal clades (with the suffix "-iformes") have been given } \\
\text { branch-based definitions, whereas familial clades (with the suffix "-idae") have been given node-based definitions } \\
\text { pertaining to crown groups. This usage has precedent in previous literature on fossil birds (e.g.: the use of Coliiformes } \\
\text { vs. Coliidae by Ksepka and Clarke [107]). Furthermore, in cases where only one family has been assigned to an order } \\
\text { (e.g.: Caprimulgidae is the only familial clade under Caprimulgiformes sensu stricto), this allows well-established } \\
\text { ordinal and familial clades to both retain utility under unranked phylogenetic classifications. Caprimulgiformes is used } \\
\text { by some taxonomic authorities to include all members of Strisores (see notes for Caprimulgimorphae); under such } \\
\text { taxonomic schemes, the clade delineated here would simply be called "total-group Caprimulgidae". }\end{array}$} \\
\hline Caprimulgidae Vigors, 1825 [108] & $\begin{array}{l}\text { The least inclusive clade including Eurostopodus mystacalis, Lyncornis } \\
\text { macrotis, and Caprimulgus europaeus }\end{array}$ \\
\hline
\end{tabular}

Notes: See notes for Caprimulgiformes. Choice of internal specifiers based on the results of Braun and Huddleston [6], Han et al. [49], Sigurðsson and Cracraft [50], and White et al. [51].

\begin{tabular}{|c|c|}
\hline Vanescaves new taxon & $\begin{array}{c}\text { The most inclusive clade including Steatornis caripensis, Nyctibius grandis, } \\
\text { Podargus strigoides, Aegotheles cristatus, and Apus apus but not } \\
\text { Caprimulgus europaeus }\end{array}$ \\
\hline \multicolumn{2}{|c|}{$\begin{array}{l}\text { Etymology: From Latin vanesco meaning "vanish" and avis meaning "bird", referring to the relictual geographic } \\
\text { distribution of many of its constituent clades, and doubles as a reference to the poem "A Route of Evanescence" by } \\
\text { Emily Dickinson, which features a hummingbird as its main subject. } \\
\text { Notes: This name is proposed to reflect a specific phylogenetic hypothesis, that steatornithids, nyctibiids, podargids, } \\
\text { and daedalornitheans form a clade exclusive of caprimulgids. This group is robustly supported by the present study as } \\
\text { well as by Prum et al. [3]. However, this name would not be recognized under studies that do not recover this clade } \\
\text { (e.g.: [2,9]). }\end{array}$} \\
\hline Steatornithiformes Mayr, 2010 [2] & $\begin{array}{c}\text { The most inclusive clade including Steatornis caripensis but not } \\
\text { Caprimulgus europaeus, Nyctibius grandis, Podargus strigoides, Aegotheles } \\
\text { cristatus, or Apus apus }\end{array}$ \\
\hline \multicolumn{2}{|c|}{$\begin{array}{l}\text { Notes: See notes for Caprimulgiformes. Under ranked taxonomic schemes that use Caprimulgiformes sensu lato, } \\
\text { the clade delineated here would simply be called "total-group Steatornithidae", though Steatornithes of Sharpe [109] } \\
\text { may be feasibly recruited. Steatornithiformes is sometimes attributed to Sharpe (e.g.: [101]), possibly because he coined } \\
\text { Steatornithes under the rank of suborder. However, the International Code of Zoological Nomenclature (ICZN) [110] } \\
\text { does not regulate taxon names ranked above the family group (as defined in ICZN Article 35.1). As such, the Principle } \\
\text { of Coordination (ICZN Article 36) does not apply to this case, and the use of Steatornithes did not automatically } \\
\text { establish the name Steatornithiformes. Thus, to our knowledge Mayr was the first to formally use Steatornithiformes, } \\
\text { as Mayr himself correctly indicated. }\end{array}$} \\
\hline Steatornithidae Bonaparte, 1842 [111] & $\begin{array}{l}\text { The least inclusive clade including all individ } \\
\text { Steatornis caripensis }\end{array}$ \\
\hline \multicolumn{2}{|c|}{ Notes: See notes for Caprimulgiformes. Monotypic. } \\
\hline Nyctibiiformes Yuri et al., 2013 [112] & $\begin{array}{l}\text { The most inclusive clade including Nyctibius grandis but not Caprimulgus } \\
\text { europaeus, Steatornis caripensis, Podargus strigoides, Aegotheles cristatus, } \\
\text { or Apus apus }\end{array}$ \\
\hline \multicolumn{2}{|c|}{$\begin{array}{l}\text { Notes: See notes for Caprimulgiformes. Under ranked taxonomic schemes that use Caprimulgiformes sensu lato, } \\
\text { the clade delineated here would simply be called "total-group Nyctibiidae". }\end{array}$} \\
\hline Nyctibiidae Chenu and des Murs, 1851 [113] & $\begin{array}{l}\text { The least inclusive clade including Phyllaemulor bracteatus, Nyctibius } \\
\text { grandis, and Nyctibius griseus }\end{array}$ \\
\hline \multicolumn{2}{|c|}{$\begin{array}{l}\text { Notes: See notes for Caprimulgiformes. Choice of internal specifiers based on the results of Braun and Huddleston [6] } \\
\text { and White et al. [114]. }\end{array}$} \\
\hline Podargiformes Mathews, 1918 [115] & $\begin{array}{c}\text { The most inclusive clade including Podargus strigoides but not } \\
\text { Caprimulgus europaeus, Steatornis caripensis, Nyctibius grandis, Aegotheles } \\
\text { cristatus, or Apus apus }\end{array}$ \\
\hline \multicolumn{2}{|c|}{$\begin{array}{l}\text { Notes: See notes for Caprimulgiformes. Under ranked taxonomic schemes that use Caprimulgiformes sensu lato, } \\
\text { the clade delineated here would simply be called "total-group Podargidae", though Podargi of Sharpe [109] may be } \\
\text { feasibly recruited. }\end{array}$} \\
\hline
\end{tabular}


Table A1. Cont.

\begin{tabular}{|c|c|}
\hline Taxon & Phylogenetic Definition \\
\hline Podargidae Bonaparte, 1838 [116] & $\begin{array}{l}\text { The least inclusive clade including Podargus strigoides, Rigidipenna } \\
\text { inexpectata, and Batrachostomus auritus }\end{array}$ \\
\hline \multicolumn{2}{|c|}{ Notes: See notes for Caprimulgiformes. Internal specifiers include all three extant genera. } \\
\hline Apodimorphae Sibley et al., 1988 [117] & $\begin{array}{c}\text { The most inclusive clade including Aegotheles cristatus and Apus apus but } \\
\text { not Caprimulgus europaeus, Steatornis caripensis, Nyctibius grandis, or } \\
\text { Podargus strigoides }\end{array}$ \\
\hline \multicolumn{2}{|c|}{$\begin{array}{l}\text { Notes: Mayr [2] recruited this name to refer to the clade uniting aegothelids and apodiforms to the exclusion of other } \\
\text { strisoreans. Although Sangster [11] had already coined the name Daedalornithes for this group, he explicitly defined } \\
\text { Daedalornithes as a crown-group clade, allowing Apodimorphae to be retained for total-group Daedalornithes. }\end{array}$} \\
\hline Daedalornithes Sangster, 2005 [11] & The least inclusive clade including Aegotheles cristatus and Apus apus \\
\hline \multicolumn{2}{|c|}{$\begin{array}{l}\text { Notes: Defined by Sangster [11]. Cracraft [98] recruited Trochiloidea for this group. Given that Sangster was the first to } \\
\text { explicitly propose a name for the clade, we favour the use of Daedalornithes here. Both total- and crown-group } \\
\text { Daedalornithes have been assigned names under our proposed phylogenetic taxonomy, so we instead recruit } \\
\text { Trochiloidea for total-group Trochilidae. }\end{array}$} \\
\hline Aegotheliformes Worthy et al., 2007 [85] & $\begin{array}{c}\text { The most inclusive clade including Aegotheles cristatus but not } \\
\text { Caprimulgus europaeus, Steatornis caripensis, Nyctibius grandis, Podargus } \\
\text { strigoides, or Apus apus }\end{array}$ \\
\hline \multicolumn{2}{|c|}{$\begin{array}{l}\text { Notes: See notes for Caprimulgiformes. This taxon is sometimes attributed to Simonetta [118] (e.g.: [85]), but Mayr [2] } \\
\text { pointed out that it should be attributed to Worthy et al. }\end{array}$} \\
\hline Aegothelidae Bonaparte, 1853 [119] & $\begin{array}{c}\text { The least inclusive clade including Aegotheles cristatus, Aegotheles savesi, } \\
\text { and Aegotheles insignis }\end{array}$ \\
\hline \multicolumn{2}{|c|}{ Notes: See notes for Caprimulgiformes. Choice of internal specifiers based on the results of Dumbacher et al. [120]. } \\
\hline Apodiformes Peters, 1940 [121] & $\begin{array}{l}\text { The most inclusive clade including Apus apus, Hemiprocne longipennis, } \\
\text { and Trochilus polytmus but not Caprimulgus europaeus, Steatornis caripensis, } \\
\text { Nyctibius grandis, Podargus strigoides, or Aegotheles cristatus }\end{array}$ \\
\hline \multicolumn{2}{|c|}{$\begin{array}{l}\text { Notes: See notes for Caprimulgiformes. Under ranked taxonomic schemes that use Caprimulgiformes sensu lato, the } \\
\text { clade delineated here is currently unnamed. }\end{array}$} \\
\hline Trochiloidea Vigors, 1825 [108] & $\begin{array}{l}\text { The most inclusive clade including Trochilus polytmus but not Apus apus } \\
\text { or Hemiprocne longipennis }\end{array}$ \\
\hline \multicolumn{2}{|c|}{ Notes: See notes for Daedalornithes. } \\
\hline Trochilidae Vigors, 1825 [108] & $\begin{array}{l}\text { The least inclusive clade including Trochilus polytmus, Topaza pella, } \\
\text { Phaethornis superciliosus, Polytmus guainumbi, and Lesbia nuna }\end{array}$ \\
\hline \multicolumn{2}{|c|}{ Notes: See notes for Caprimulgiformes. Choice of internal specifiers based on the results of McGuire et al. [122]. } \\
\hline Apodi Peters, 1940 [121] & The least inclusive clade including Apus apus and Hemiprocne longipennis \\
\hline \multicolumn{2}{|c|}{$\begin{array}{l}\text { Notes: This name has consistently been used in reference to the group uniting Hemiprocnidae and Apodidae [2,57,121]. } \\
\text { As such, this is reflected in our proposed definition. }\end{array}$} \\
\hline Hemiprocnidae Oberholser, 1906 [123] & $\begin{array}{l}\text { The least inclusive clade including Hemiprocne longipennis, Hemiprocne } \\
\text { coronata, Hemiprocne comata, and Hemiprocne mystacea }\end{array}$ \\
\hline \multicolumn{2}{|c|}{ Notes: See notes for Caprimulgiformes. Internal specifiers include all four extant species. } \\
\hline Apodidae Olphe-Galliard, 1887 [124] & $\begin{array}{l}\text { The least inclusive clade including Apus apus, Cypseloides fumigatus, } \\
\text { Streptoprocne zonaris, Collocalia esculenta, and Chaetura pelagica }\end{array}$ \\
\hline Notes: See notes for Caprimulgiformes. In & $\begin{array}{l}\text { nal specifiers based on the results of Price et al. [125], Thomassen et al. } \\
\text { 26], and Päckert et al. [127]. }\end{array}$ \\
\hline
\end{tabular}

\section{Appendix B}

Select character states that were optimized as synapomorphies of notable clades in the present study (see main text) are illustrated below, alongside the plesiomorphic state for each character. Some features are denoted by red markers as appropriate. Character states that were already figured by Mayr [2,37] are not illustrated. 


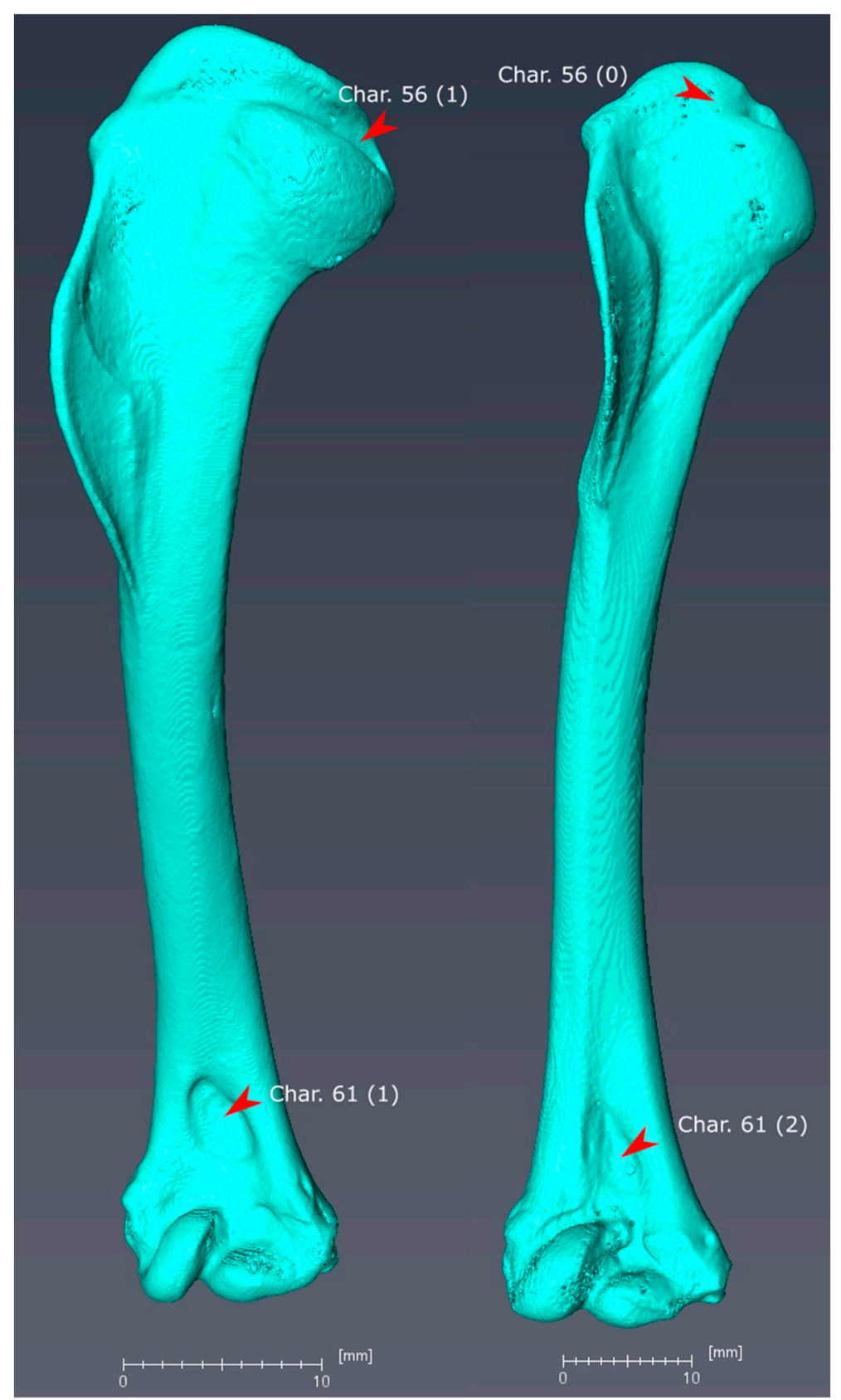

Figure A1. Humeri of Nyctibius griseus (left) and Podargus strigoides (right) in cranial view. Nyctibius exhibits state 1 for character 56 (transverse sulcus on humerus very deep, long, and rectangular, optimized as a synapomorphy of Strisores), whereas Podargus exhibits state 0 (transverse sulcus on humerus not deep, long, and rectangular, optimized as a synapomorphy of Podargiformes). Nyctibius also exhibits state 1 for character 61 (shallow fossa m. brachialis on humerus), whereas Podargus exhibits state 2 (deep fossa $\mathrm{m}$. brachialis on humerus, optimized as a synapomorphy for Podargiformes as well as Steatornithiformes). Note that even though Podargus has a fossa m. brachialis of greater depth, the rim of the fossa is of steeper relief in Nyctibius. 


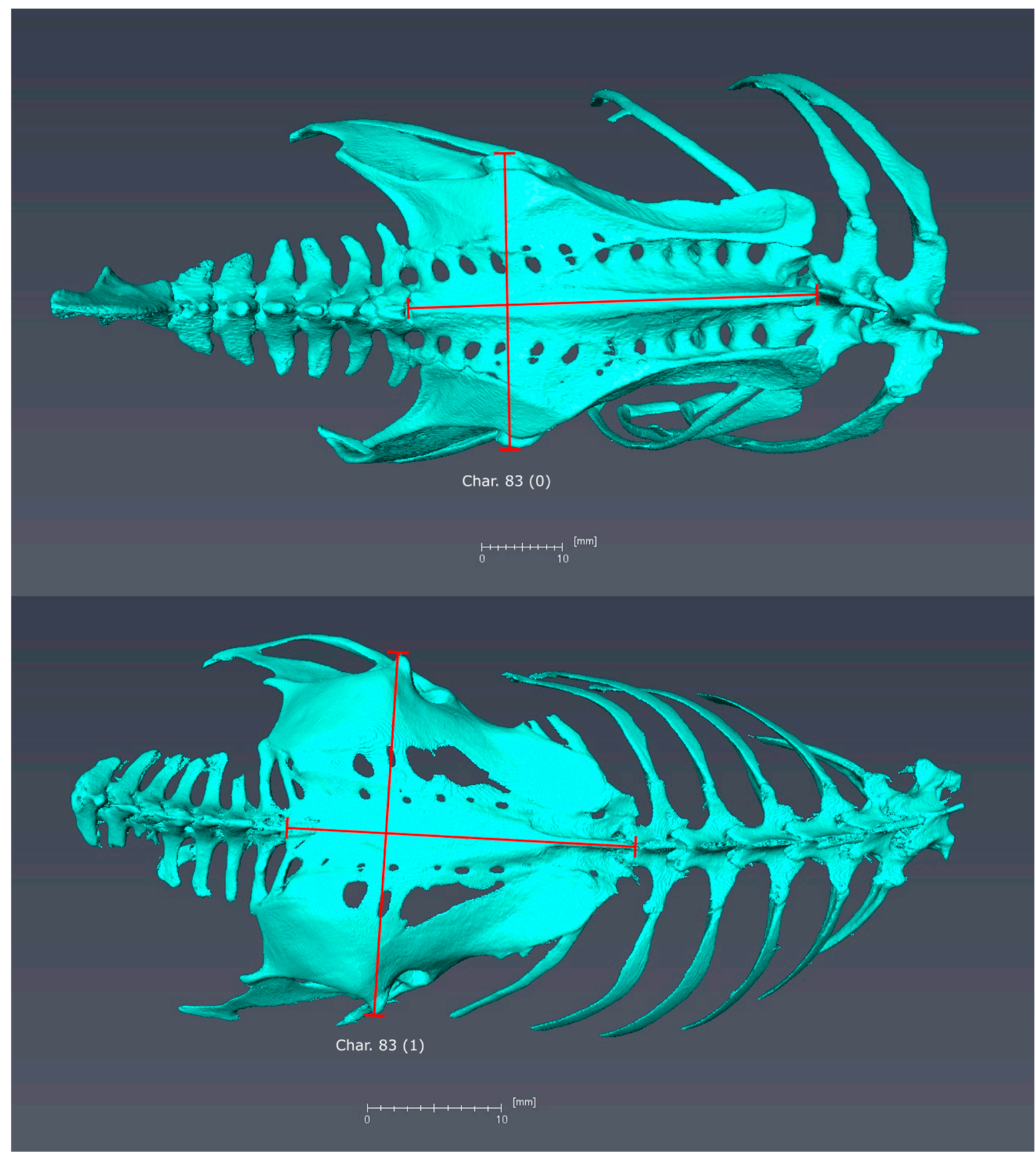

Figure A2. Synsacra of Podargus strigoides (top) and Streptoprocne zonaris (bottom) in dorsal view. Podargus exhibits state 0 for character 83 (pelvis width across antitrochanters less than length of synsacrum), whereas Streptoprocne exhibits state 1 (pelvis width across antitrochanters greater than length of synsacrum, optimized as a synapomorphy of Daedalornithes as well as Caprimulgiformes). 


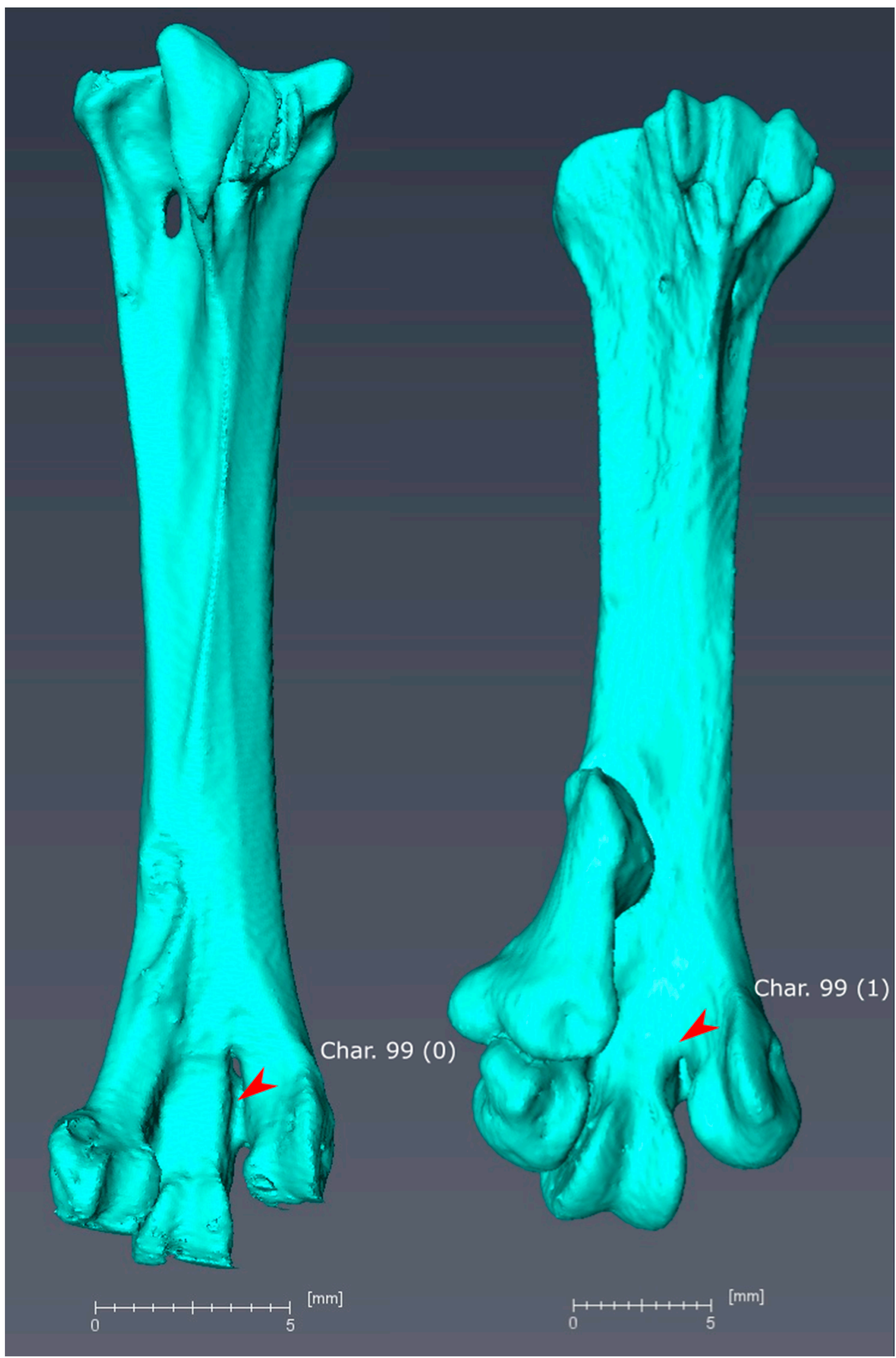

Figure A3. Tarsometatarsi of Columba livia (left) and Podargus strigoides (right) in plantar view. Columba exhibits state 0 for character 99 (distal interosseus canal of tarsometatarsus present), whereas Podargus exhibits state 1 (distal interosseus canal of tarsometatarsus absent, optimized as a synapomorphy of Podargidae + Daedaelornithes). 

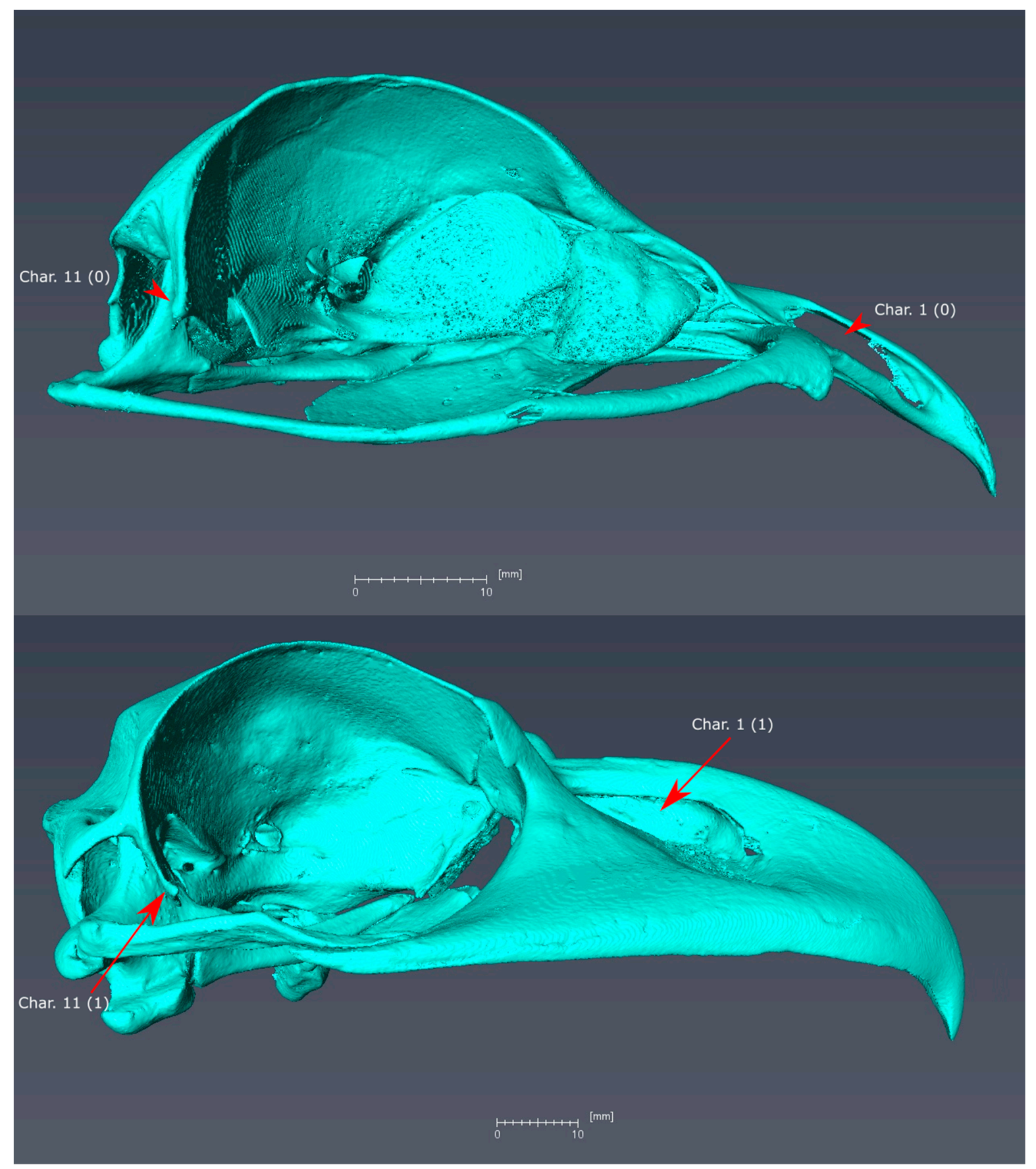

Figure A4. Crania of Nyctibius griseus (top) and Podargus strigoides (bottom) in lateral view. Nyctibius exhibits state 0 for character 1 (ossified nasal septum absent), whereas Podargus exhibits state 1 (ossified nasal septum present, optimized as a synapomorphy of Podargiformes). Nyctibius also exhibits state 0 for character 11 (postorbital process short and not approaching the jugal bar), whereas Podargus exhibits state 1 (postorbital process elongated such that it nearly touches the jugal bar, optimized as a synapomorphy of Podargiformes). 


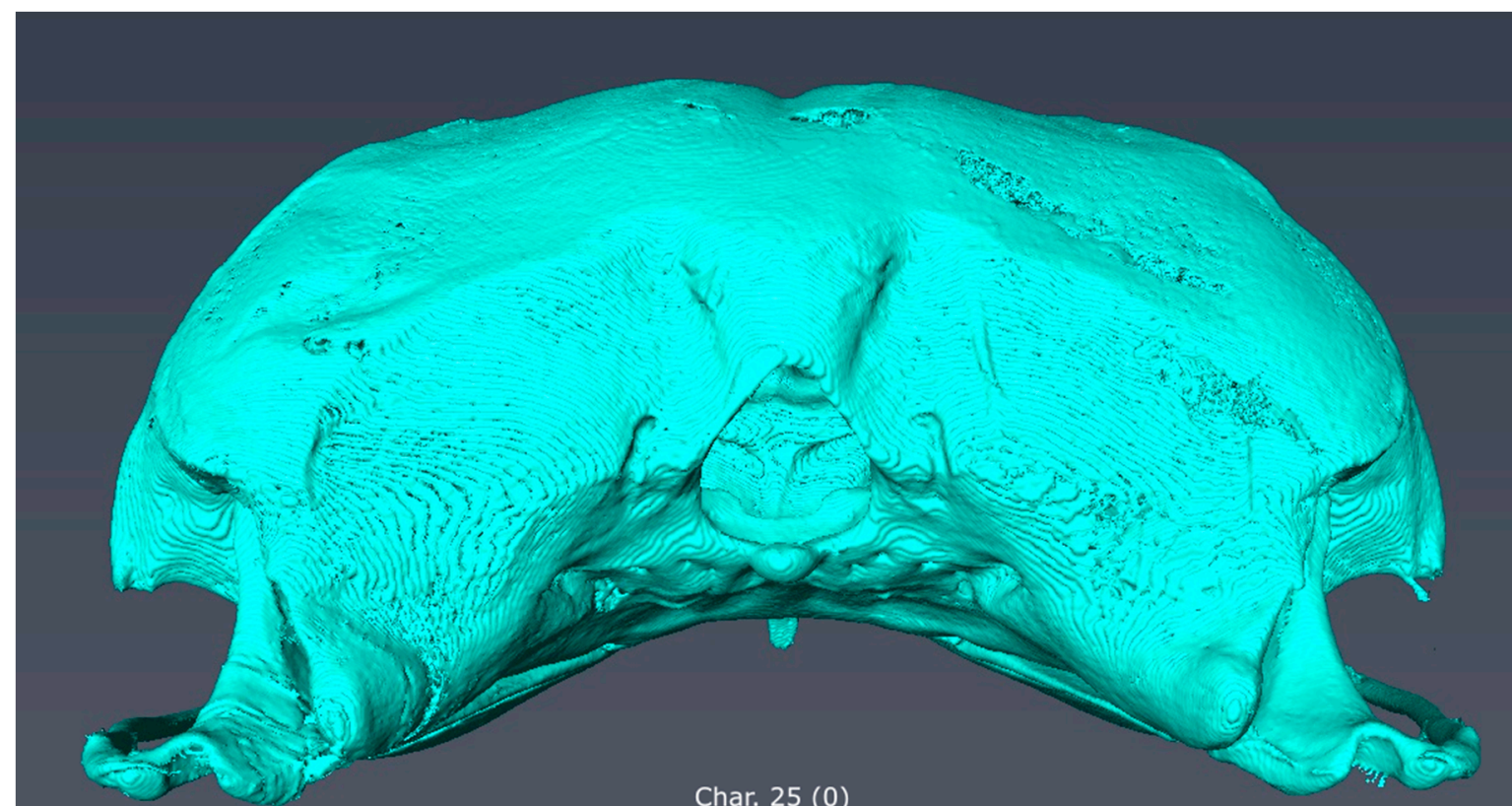

Char. $25(0)$
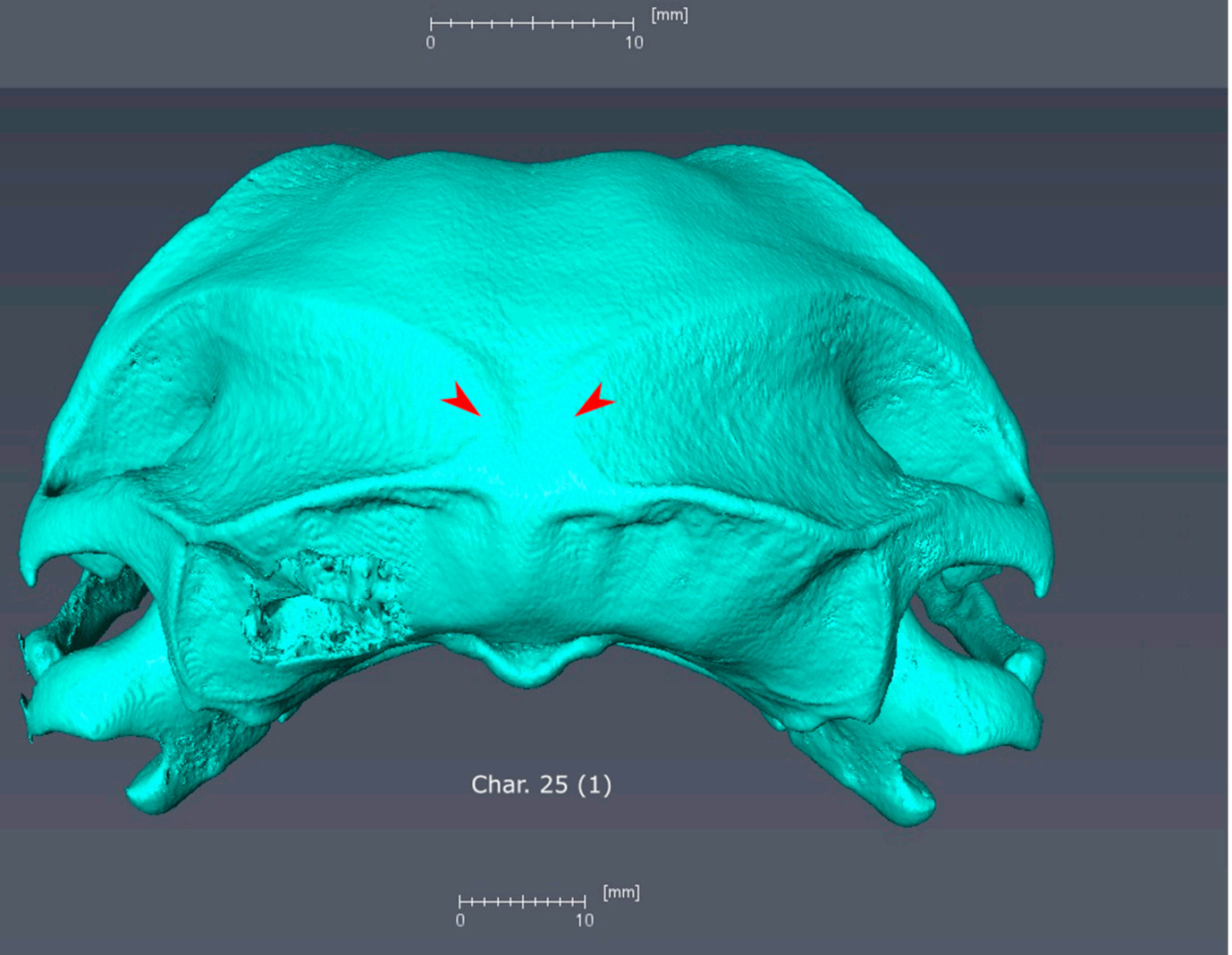

Figure A5. Crania of Nyctibius griseus (top) and Podargus strigoides (bottom) in posterior view. Nyctibius exhibits state 0 for character 25 (temporal fossae of parietals absent or far from midline), whereas Podargus exhibits state 1 (temporal fossae of parietals meeting or almost meeting at midline, optimized as a synapomorphy of Podargiformes). 


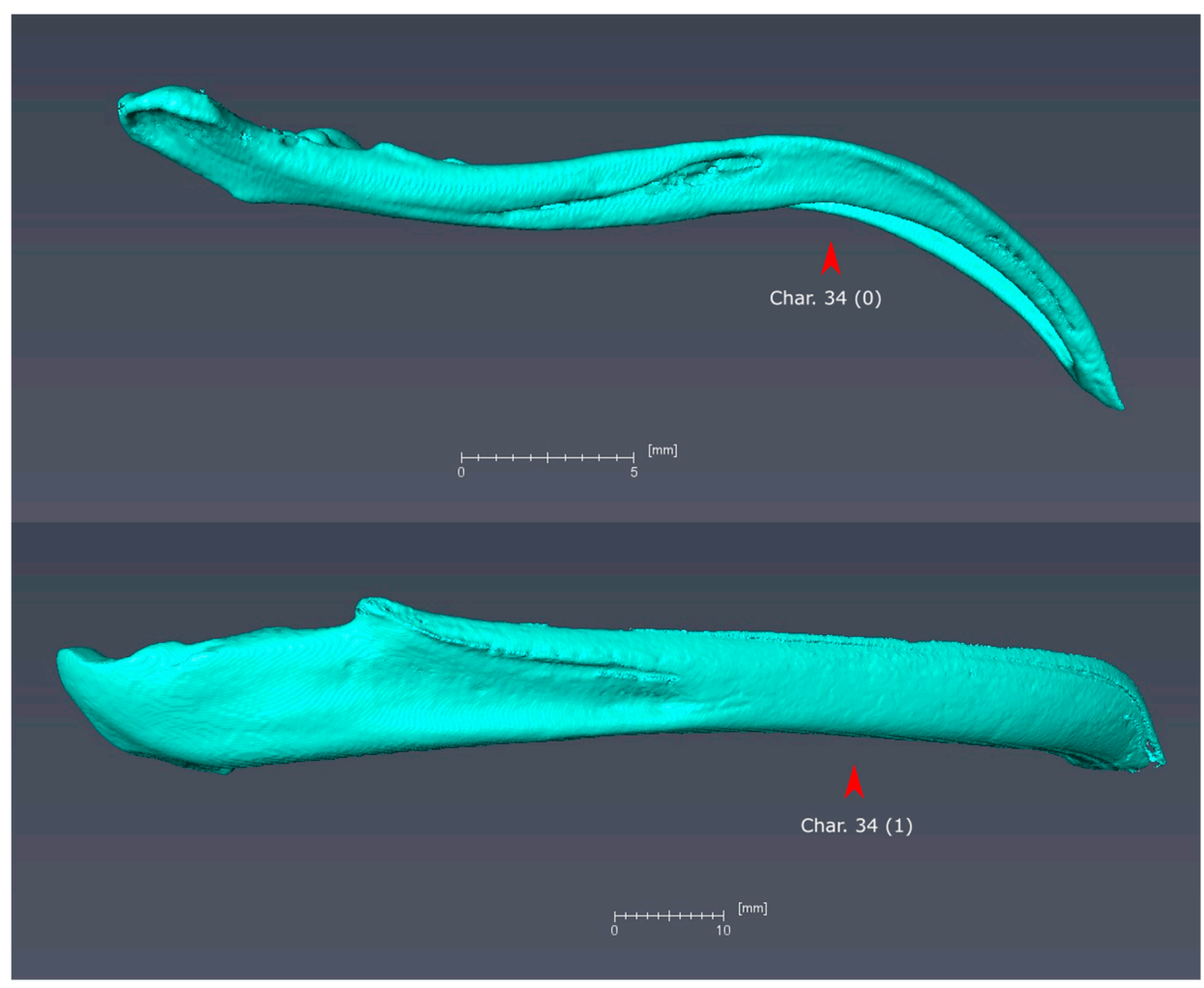

Figure A6. Mandibles of Streptoprocne zonaris (top) and Podargus (bottom) in right lateral view. Streptoprocne exhibits state 0 for character 34 (ventral margin of mandibular rami decurved in lateral view), whereas Podargus exhibits state 1 (ventral margin of mandibular rami virtually straight in lateral view, optimized as a synapomorphy of Podargiformes).

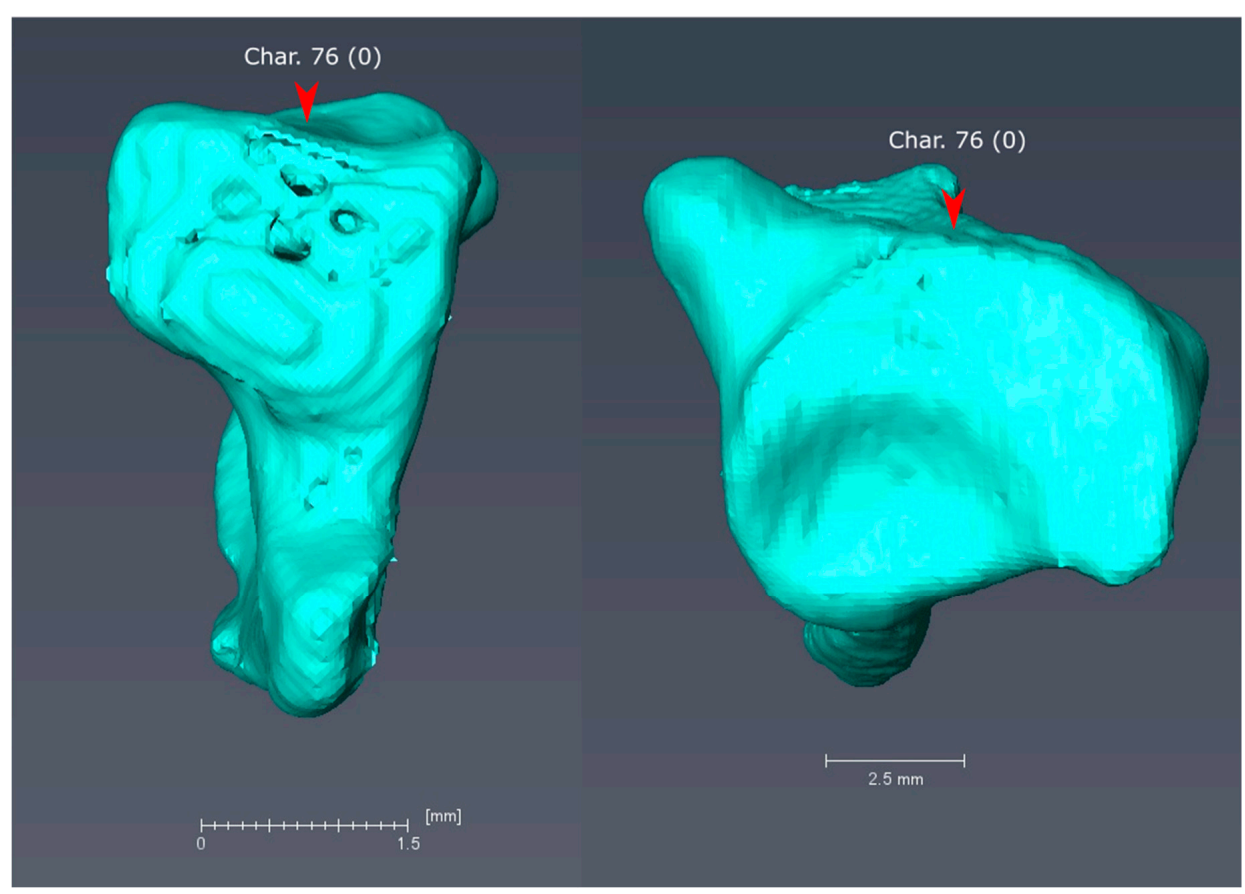

Figure A7. Manual phalanges II-1 of Aegotheles cristatus (left) and Podargus strigoides (right) in distal view. Arrows indicate the cranial facies. Aegotheles exhibits state 0 for character 76 (cranial face of manual phalanx II-1 narrow), whereas Podargus exhibits state 1 (cranial face of manual phalanx II-1 widened, optimized as a synapomorphy of Podargiformes). 

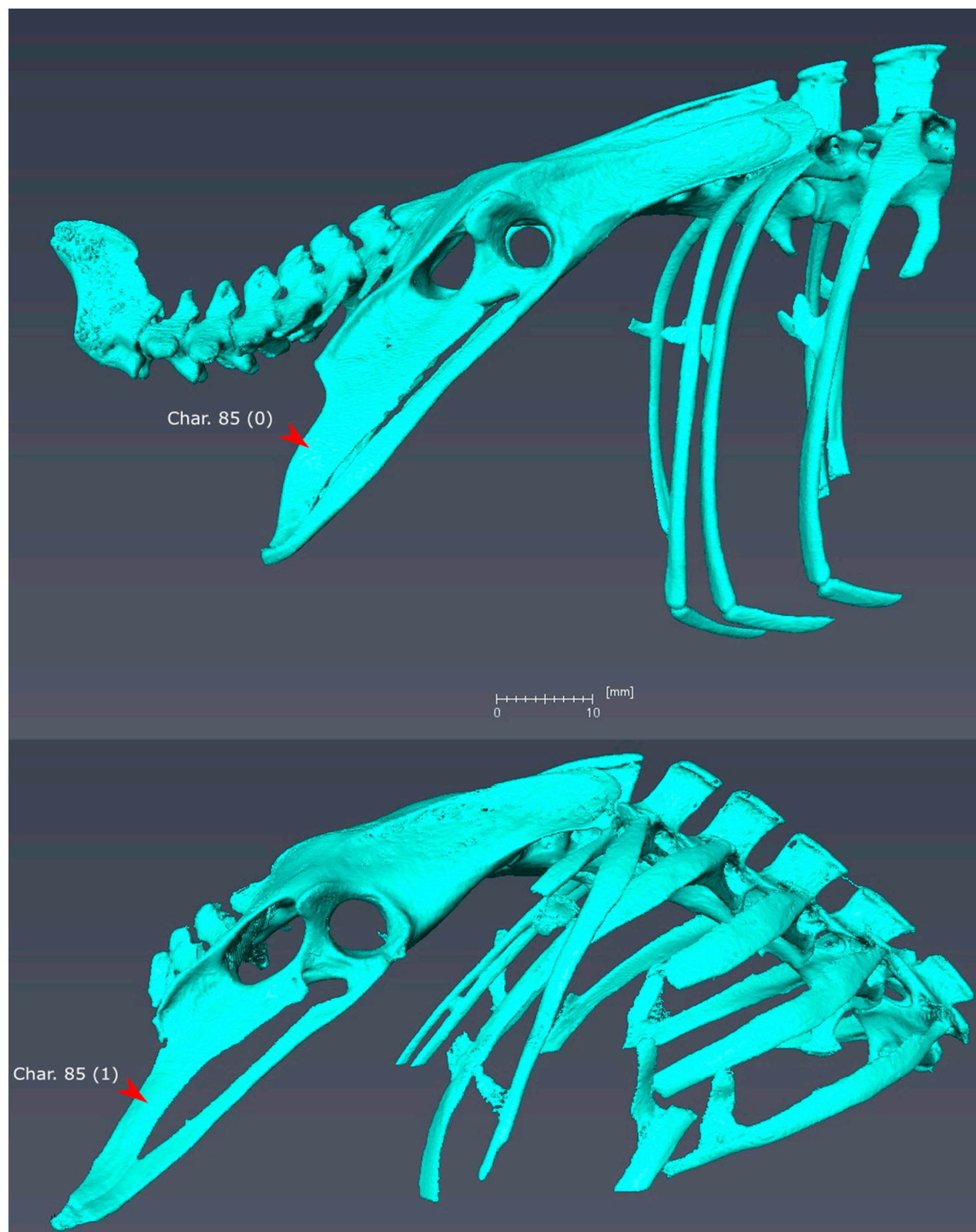

$+1+1+1+1[\mathrm{~mm}]$

Figure A8. Pelvic girdles of Podargus strigoides (top) and Aegotheles cristatus (bottom) in right lateral view. Podargus exhibits state 0 for character 85 (terminal portion of ischium not slender), whereas Aegotheles exhibits state 1 (terminal portion of ischium slender, creating wide ischiopubic fenestra, optimized as a synapomorphy of Daedalornithes). 

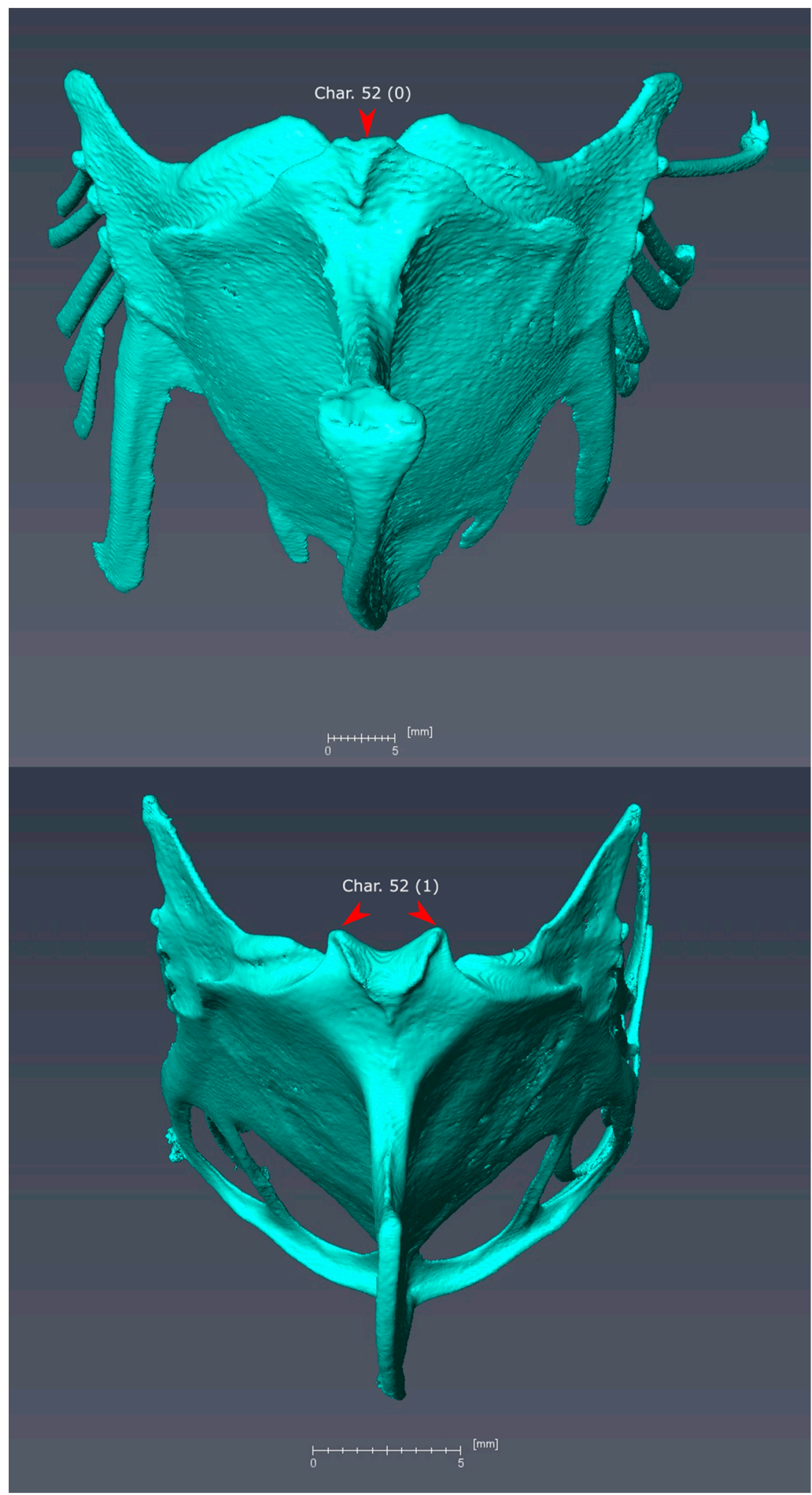

Figure A9. Sterna of Podargus strigoides (top) and Aegotheles cristatus (bottom) in cranioventral view. Podargus exhibits state 0 for character 52 (single external spine of sternum), whereas Aegotheles exhibits state 1 (bifurcated external spine of sternum, a shared feature with Hassiavis). 


\section{References}

1. Hackett, S.J.; Kimball, R.T.; Reddy, S.; Bowie, R.C.K.; Braun, E.L.; Braun, M.J.; Chojnowski, J.L.; Cox, W.A.; Han, K.-L.; Harshman, J.; et al. A phylogenomic study of birds reveals their evolutionary history. Science 2008, 320, 1763-1768. [CrossRef] [PubMed]

2. Mayr, G. Phylogenetic relationships of the paraphyletic 'caprimulgiform' birds (nightjars and allies). J. Zool. Syst. Evol. Res. 2010, 48, 126-137. [CrossRef]

3. Prum, R.O.; Berv, J.S.; Dornburg, A.; Field, D.J.; Townsend, J.P.; Lemmon, E.M.; Lemmon, A.R. A comprehensive phylogeny of birds (Aves) using targeted next-generation DNA sequencing. Nature 2015, 526, 569-573. [CrossRef] [PubMed]

4. Mayr, G. Osteological evidence for paraphyly of the avian order Caprimulgiformes (nightjars and allies). J. Ornithol. 2002, 143, 82-97. [CrossRef]

5. Ericson, P.G.P.; Anderson, C.L.; Britton, T.; Elzanowski, A.; Johansson, U.S.; Källersjö, M.; Ohlson, J.I.; Parsons, T.J.; Zuccon, D.; Mayr, G. Diversification of Neoaves: Integration of molecular sequence data and fossils. Biol. Lett. 2006, 2, 543-547. [CrossRef] [PubMed]

6. Braun, M.J.; Huddleston, C.J. A molecular phylogenetic survey of caprimulgiform nightbirds illustrates the utility of non-coding sequences. Mol. Phylogenet. Evol. 2009, 53, 948-960. [CrossRef] [PubMed]

7. Kimball, R.T.; Wang, N.; Heimer-McGinn, V.; Ferguson, C.; Braun, E.L. Identifying localized biases in large datasets: A case study using the avian tree of life. Mol. Phylogenet. Evol. 2013, 69, 1021-1032. [CrossRef]

8. Ksepka, D.T.; Clarke, J.A.; Nesbitt, S.J.; Kulp, F.B.; Grande, L. Fossil evidence of wing shape in a stem relative of swifts and hummingbirds (Aves, Pan-Apodiformes). Proc. R. Soc. B Biol. Sci. 2013, 280, 20130580. [CrossRef]

9. Reddy, S.; Kimball, R.T.; Pandey, A.; Hosner, P.A.; Braun, M.J.; Hackett, S.J.; Han, K.-L.; Harshman, J.; Huddleston, C.J.; Kingston, S.; et al. Why do phylogenomic data sets yield conflicting trees? Data type influences the avian tree of life more than taxon sampling. Syst. Biol. 2017, 66, 857-879. [CrossRef]

10. White, N.D.; Braun, M.J. Extracting phylogenetic signal from phylogenomic data: Higher-level relationships of the nightbirds (Strisores). Mol. Phylogenet. Evol. 2019, accepted.

11. Sangster, G. A name for the clade formed by owlet-nightjars, swifts and hummingbirds (Aves). Zootaxa 2005, 799, 1-6. [CrossRef]

12. Smithwick, F.M.; Brayley, O.; Field, D.J.; Mayr, G.; Vinther, J. Palaeocolour reconstructions support ancestral nocturnality of strisorian birds. (manuscript in preparation).

13. Tagliacollo, V.A.; Bernt, M.J.; Craig, J.M.; Oliveira, C.; Albert, J.S. Model-based total evidence phylogeny of Neotropical electric knifefishes (Teleostei, Gymnotiformes). Mol. Phylogenet. Evol. 2016, 95, 20-33. [CrossRef] [PubMed]

14. Grande, T.C.; Borden, W.C.; Wilson, M.V.H.; Scarpitta, L. Phylogenetic relationships among fishes in the order Zeiformes based on molecular and morphological data. Copeia 2018, 106, 20-48. [CrossRef]

15. Martin, R.P.; Olson, E.E.; Girard, M.G.; Smith, W.L.; Davis, M.P. Light in the darkness: New perspective on lanternfish relationships and classification using genomic and morphological data. Mol. Phylogenet. Evol. 2018, 121, 71-85. [CrossRef] [PubMed]

16. Bagley, J.C.; Mayden, R.L.; Harris, P.M. Phylogeny and divergence times of suckers (Cypriniformes: Catostomidae) inferred from Bayesian total-evidence analyses of molecules, morphology, and fossils. Peer 2018, 6, e5168. [CrossRef] [PubMed]

17. O'Leary, M.A.; Bloch, J.I.; Flynn, J.J.; Gaudin, T.J.; Giallombardo, A.; Giannini, N.P.; Goldberg, S.L.; Kraatz, B.P.; Luo, Z.-X.; Meng, J.; et al. The placental mammal ancestor and the post-K-Pg radiation of placentals. Science 2013, 339, 662-667. [CrossRef]

18. Halliday, T.J.D.; Upchurch, P.; Goswami, A. Resolving the relationships of Paleocene placental mammals: Paleocene mammal phylogeny. Biol. Rev. 2017, 92, 521-550. [CrossRef]

19. Reeder, T.W.; Townsend, T.M.; Mulcahy, D.G.; Noonan, B.P.; Wood, P.L.; Sites, J.W.; Wiens, J.J. Integrated analyses resolve conflicts over squamate reptile phylogeny and reveal unexpected placements for fossil taxa. PLoS ONE 2015, 10, e0118199. [CrossRef]

20. Gauthier, J.; Kluge, A.G.; Rowe, T. Amniote phylogeny and the importance of fossils. Cladistics 1988, 4, 105-209. [CrossRef] 
21. Donoghue, M.J.; Doyle, J.A.; Gauthier, J.; Kluge, A.G.; Rowe, T. The importance of fossils in phylogeny reconstruction. Annu. Rev. Ecol. Syst. 1989, 20, 431-460. [CrossRef]

22. Mayr, G. The higher-level phylogeny of birds-When morphology, molecules, and fossils coincide. Oryctos 2008, 7, 67-73.

23. Mayr, G. The origins of crown group birds: Molecules and fossils. Palaeontology 2014, 57, 231-242. [CrossRef]

24. Hsiang, A.Y.; Field, D.J.; Webster, T.H.; Behlke, A.D.; Davis, M.B.; Racicot, R.A.; Gauthier, J.A. The origin of snakes: Revealing the ecology, behavior, and evolutionary history of early snakes using genomics, phenomics, and the fossil record. BMC Evol. Biol. 2015, 15, 87. [CrossRef] [PubMed]

25. Asher, R.J.; Smith, M.R.; Rankin, A.; Emry, R.J. Congruence, fossils and the evolutionary tree of rodents and lagomorphs. R. Soc. Open Sci. 2019, 6, 190387. [CrossRef] [PubMed]

26. Miyashita, T.; Coates, M.I.; Farrar, R.; Larson, P.; Manning, P.L.; Wogelius, R.A.; Edwards, N.P.; Anné, J.; Bergmann, U.; Palmer, A.R.; et al. Hagfish from the Cretaceous Tethys Sea and a reconciliation of the morphological-molecular conflict in early vertebrate phylogeny. Proc. Natl. Acad. Sci. USA 2019, 116, 2146-2151. [CrossRef] [PubMed]

27. Parham, J.F.; Donoghue, P.C.J.; Bell, C.J.; Calway, T.D.; Head, J.J.; Holroyd, P.A.; Inoue, J.G.; Irmis, R.B.; Joyce, W.G.; Ksepka, D.T.; et al. Best practices for justifying fossil calibrations. Syst. Biol. 2012, 61, 346-359. [CrossRef]

28. Giribet, G. Morphology should not be forgotten in the era of genomics-A phylogenetic perspective. Zool. Anz. 2015, 256, 96-103. [CrossRef]

29. Lee, M.S.Y.; Palci, A. Morphological phylogenetics in the genomic age. Curr. Biol. 2015, 25, R922-R929. [CrossRef]

30. Mayr, G. Paleogene Fossil Birds; Springer: Berlin, Germany, 2009.

31. Mayr, G. Avian Evolution: The Fossil Record of Birds and Its Paleobiological Significance; Wiley-Blackwell: Chichester, UK, 2017.

32. Olson, S.L. An early Eocene oilbird from the Green River Formation of Wyoming (Caprimulgiformes: Steatornithidae). Doc. Lab. Géol. 1987, 99, 57-69.

33. Mourer-Chauviré, C. New data concerning the familial position of the genus Euronyctibius (Aves, Caprimulgiformes) from the Paleogene of the Phosphorites du Quercy, France. Paleontol. J. 2013, 47, 1315-1322. [CrossRef]

34. Mayr, G. The Palaeogene Old World potoo Paraprefica Mayr, 1999 (Aves, Nyctibiidae): Its osteology and affinities to the New World Preficinae Olson, 1987. J. Syst. Palaeontol. 2005, 3, 359-370. [CrossRef]

35. Mayr, G. Caprimulgiform birds from the Middle Eocene of Messel (Hessen, Germany). J. Vertebr. Paleontol. 1999, 19, 521-532. [CrossRef]

36. Nesbitt, S.J.; Ksepka, D.T.; Clarke, J.A. Podargiform affinities of the enigmatic Fluvioviridavis platyrhamphus and the early diversification of Strisores ("Caprimulgiformes" + Apodiformes). PLoS ONE 2011, 6, e26350. [CrossRef] [PubMed]

37. Mayr, G. Eocene fossils and the early evolution of frogmouths (Podargiformes): Further specimens of Masillapodargus and a comparison with Fluvioviridavis. Palaeobiodivers. Palaeoenviron. 2015, 95, 587-596. [CrossRef]

38. Mayr, G. Reappraisal of Eocypselus-A stem group apodiform from the early Eocene of Northern Europe. Palaeobiodivers. Palaeoenviron. 2010, 90,395-403. [CrossRef]

39. Mayr, G. Skeletal morphology of the middle Eocene swift Scaniacypselus and the evolutionary history of true swifts (Apodidae). J. Ornithol. 2015, 156, 441-450. [CrossRef]

40. Mayr, G. Phylogeny of early Tertiary swifts and hummingbirds (Aves: Apodiformes). Auk 2003, 120, $145-151$. [CrossRef]

41. Mayr, G. Old World fossil record of modern-type hummingbirds. Science 2004, 304, 861-864. [CrossRef]

42. Bochenski, Z.; Bochenski, Z.M. An Old World hummingbird from the Oligocene: A new fossil from Polish Carpathians. J. Ornithol. 2008, 149, 211-216. [CrossRef]

43. Louchart, A.; Tourment, N.; Carrier, J.; Roux, T.; Mourer-Chauviré, C. Hummingbird with modern feathering: An exceptionally well-preserved Oligocene fossil from southern France. Naturwissenschaften 2008, 95, 171-175. [CrossRef] [PubMed] 
44. Jarvis, E.D.; Mirarab, S.; Aberer, A.J.; Li, B.; Houde, P.; Li, C.; Ho, S.Y.W.; Faircloth, B.C.; Nabholz, B.; Howard, J.T.; et al. Whole-genome analyses resolve early branches in the tree of life of modern birds. Science 2014, 346, 1320-1331. [CrossRef] [PubMed]

45. Harris, J.D.; Lamanna, M.C.; You, H.; Ji, S.; Ji, Q. A second enantiornithean (Aves: Ornithothoraces) wing from the Early Cretaceous Xiagou Formation near Changma, Gansu Province, People's Republic of China. Can. J. Earth Sci. 2006, 43, 547-554. [CrossRef]

46. Bostwick, K.S.; Brady, M.J. Phylogenetic analysis of wing feather taxis in birds: Macroevolutionary patterns of genetic drift? Auk 2002, 119, 943-954. [CrossRef]

47. Del Hoyo, J.; Elliott, A.; Sargatal, J.; Christie, D.A.; de Juana, E. Handbook of the Birds of the World Alive. Available online: https://www.hbw.com/ (accessed on 3 August 2019).

48. Cleere, N. Nightjars, Potoos, Frogmouths, Oilbird, and Owlet-nightjars of the World; Princeton University Press: Princeton, NJ, USA, 2010.

49. Han, K.-L.; Robbins, M.B.; Braun, M.J. A multi-gene estimate of phylogeny in the nightjars and nighthawks (Caprimulgidae). Mol. Phylogenet. Evol. 2010, 55, 443-453. [CrossRef] [PubMed]

50. Sigurðsson, S.; Cracraft, J. Deciphering the diversity and history of New World nightjars (Aves: Caprimulgidae) using molecular phylogenetics: Phylogeny of New World Nightjars. Zool. J. Linn. Soc. 2014, 170, 506-545. [CrossRef]

51. White, N.D.; Barrowclough, G.F.; Groth, J.G.; Braun, M.J. A multi-gene estimate of higher-level phylogenetic relationships among nightjars (Aves: Caprimulgidae). Ornitol. Neotrop. 2016, 27, 223-236.

52. Mayr, G. Ein Archaeotrogon (Aves: Archaeotrogonidae) aus dem Mittel-Eozän der Grube Messel (Hessen, Deutschland)? J. Ornithol. 1998, 139, 121-129. [CrossRef]

53. Mayr, G. New specimens of Hassiavis laticauda (Aves: Cypselomorphae) and Quasisyndactylus longibrachis (Aves: Alcediniformes) from the Middle Eocene of Messel, Germany. Cour. Forschungsinstitut Senckenburg 2004, 252, 23-28.

54. Ksepka, D.T.; Clarke, J.A. Phylogenetically vetted and stratigraphically constrained fossil calibrations within Aves. Palaeontol. Electron. 2015, 18. [CrossRef]

55. Mayr, G. A new cypselomorph bird from the middle Eocene of Germany and the early diversification of avian aerial insectivores. Condor 2005, 107, 342-352. [CrossRef]

56. Mayr, G.; Daniels, M. A new short-legged landbird from the early Eocene of Wyoming and contemporaneous European sites. Acta Palaeontol. Pol. 2001, 46, 393-402.

57. Harrison, C.J.O. A revision of the fossil swifts (Vertebrata, Aves, suborder Apodi), with descriptions of three new genera and two new species. Meded. Werkgr. Voor Tert. Kwartaire Geol. 1984, 21, 157-177.

58. Dyke, G.J.; Waterhouse, D.M.; Kristoffersen, A.V. Three new fossil landbirds from the early Paleogene of Denmark. Bull. Geol. Soc. Den. 2004, 51,77-85.

59. Peters, D.S. Ein neuer Segler aus der Grube Messel und seine Bedeutung für den Status der Aegialornithidae (Aves: Apodiformes). Senckenberg. Lethaea 1985, 66, 143-164.

60. Mayr, G.; Peters, D.S. On the systematic position of the Middle Eocene swift Aegialornis szarskii Peters 1985 with description of a new swift-like bird from Messel (Aves, Apodiformes). Neues Jahrb. Geol. Paläontol. 1999, 1999, 312-320.

61. Mourer-Chauviré, C. Les Aegialornithidae (Aves: Apodiformes) des Phosphorites du Quercy. Comparaison avec la forme de Messel. Cour. Forschungsinstitut Senckenberg 1988, 107, 369-381.

62. Mayr, G. A new Eocene swift-like bird with a peculiar feathering. Ibis 2003, 145, 382-391. [CrossRef]

63. Karhu, A.A. A new genus and species of the family Jungornithidae (Apodiformes) from the late Eocene of the Northern Caucasus, with comments on the ancestry of hummingbirds. Smithson. Contrib. Paleobiol. 1999, 89, 207-216.

64. Karhu, A.A. Novoye semeystvo strizheobraznykh iz paleogena Yevropy. Paleontol. J. 1988, 3, $78-88$.

65. Mayr, G. New specimens of the early Oligocene Old World hummingbird Eurotrochilus inexpectatus. J. Ornithol. 2007, 148, 105-111. [CrossRef]

66. Mayr, G.; Micklich, N. New specimens of the avian taxa Eurotrochilus (Trochilidae) and Palaeotodus (Todidae) from the early Oligocene of Germany. Paläontol. Z. 2010, 84, 387-395. [CrossRef]

67. Huelsenbeck, J.P.; Ronquist, F. MRBAYES: Bayesian inference of phylogenetic trees. Bioinformatics 2001, 17, 754-755. [CrossRef] [PubMed] 
68. Ronquist, F.; Huelsenbeck, J.P. MrBayes 3: Bayesian phylogenetic inference under mixed models. Bioinformatics 2003, 19, 1572-1574. [CrossRef] [PubMed]

69. Miller, M.A.; Pfeiffer, W.; Schartz, T. Creating the CIPRES Science Gateway for inference of large phylogenetic trees. In Proceedings of the Gateway Computing Environments Workshop (GCE); IEEE Press: Piscataway, NJ, USA, 2010; pp. 1-8.

70. Lewis, P.O. A likelihood approach to estimating phylogeny from discrete morphological character data. Syst. Biol. 2001, 50, 913-925. [CrossRef] [PubMed]

71. Yang, Z. Estimating the pattern of nucleotide substitution. J. Mol. Evol. 1994, 39, 105-111. [CrossRef] [PubMed]

72. Rambaut, A.; Drummond, A.J.; Xie, D.; Baele, G.; Suchard, M.A. Posterior summarization in Bayesian phylogenetics using Tracer 1.7. Syst. Biol. 2018, 67, 901-904. [CrossRef] [PubMed]

73. Goloboff, P.A.; Catalano, S.A. TNT version 1.5, including a full implementation of phylogenetic morphometrics. Cladistics 2016, 32, 221-238. [CrossRef]

74. O'Reilly, J.E.; Puttick, M.N.; Parry, L.; Tanner, A.R.; Tarver, J.E.; Fleming, J.; Pisani, D.; Donoghue, P.C.J. Bayesian methods outperform parsimony but at the expense of precision in the estimation of phylogeny from discrete morphological data. Biol. Lett. 2016, 12, 20160081. [CrossRef]

75. Kimball, R.T.; Oliveros, C.H.; Wang, N.; White, N.D.; Barker, F.K.; Field, D.J.; Ksepka, D.T.; Chesser, R.T.; Moyle, R.G.; Braun, M.J.; et al. A phylogenomic supertree of birds. Diversity 2019, 11, 109. [CrossRef]

76. Ksepka, D.T.; Stidham, T.A.; Williamson, T.E. Early Paleocene landbird supports rapid phylogenetic and morphological diversification of crown birds after the K-Pg mass extinction. Proc. Natl. Acad. Sci. USA 2017, 114, 8047-8052. [CrossRef] [PubMed]

77. Berv, J.S.; Field, D.J. Genomic signature of an avian Lilliput Effect across the K-Pg extinction. Syst. Biol. 2018, 67, 1-13. [CrossRef] [PubMed]

78. Field, D.J.; Berv, J.S.; Hsiang, A.Y.; Lanfear, R.; Landis, M.J.; Dornburg, A. Timing the extant avian radiation: The rise of modern birds, and the importance of modeling molecular rate variation. Peer J. Prepr. 2019, 7, e27521v1.

79. Worthy, T.H.; Degrange, F.J.; Handley, W.D.; Lee, M.S.Y. The evolution of giant flightless birds and novel phylogenetic relationships for extinct fowl (Aves, Galloanseres). R. Soc. Open Sci. 2017, 4, 170975. [CrossRef] [PubMed]

80. Cracraft, J. Toward a phylogenetic classification of the recent birds of the world (class Aves). Auk 1981, 98, 681-714.

81. Cracraft, J. The major clades of birds. In The Phylogeny and Classification of the Tetrapods Volume 1: Amphibians, Reptiles, Birds; Benton, M.J., Ed.; Oxford University Press: Oxford, UK, 1988; pp. 339-361.

82. Mayr, G. Avian higher-level phylogeny: Well-supported clades and what we can learn from a phylogenetic analysis of 2954 morphological characters. J. Zool. Syst. Evol. Res. 2008, 46, 63-72. [CrossRef]

83. Laing, A.M.; Doyle, S.; Gold, M.E.L.; Nesbitt, S.J.; O’Leary, M.A.; Turner, A.H.; Wilberg, E.W.; Poole, K.E. Giant taxon-character matrices: The future of morphological systematics. Cladistics 2018, 34, 333-335. [CrossRef]

84. Rich, P.V.; McEvey, A. A new owlet-nightjar from the early to mid-Miocene of eastern New South Wales. Mem. Natl. Mus. Vic. 1977, 38, 247-253. [CrossRef]

85. Worthy, T.H.; Tennyson, A.J.D.; Jones, C.; McNamara, J.A.; Douglas, B.J. Miocene waterfowl and other birds from central Otago, New Zealand. J. Syst. Palaeontol. 2007, 5, 1-39. [CrossRef]

86. Mourer-Chauviré, C. Les oiseaux fossiles des phosphorites du quercy (éocène supérieur a oligocène supérieur): Implications paléobiogéographiques. Geobios 1982, 15, 413-426. [CrossRef]

87. Mourer-Chauviré, C. Les relations entre les avifaunes du Tertiaire inferieur d'Europe et d'Amerique du Sud. Bull. Soc. Géol. Fr. 1999, 170, 85-90.

88. Mayr, G. Two-phase extinction of "Southern Hemispheric" birds in the Cenozoic of Europe and the origin of the Neotropic avifauna. Palaeobiodivers. Palaeoenviron. 2011, 91, 325-333. [CrossRef]

89. Mayr, G. Avian higher level biogeography: Southern Hemispheric origins or Southern Hemispheric relicts? J. Biogeogr. 2017, 44, 956-958. [CrossRef]

90. Field, D.J.; Hsiang, A.Y. A North American stem turaco, and the complex biogeographic history of modern birds. BMC Evol. Biol. 2018, 18, 102. [CrossRef] [PubMed] 
91. Saupe, E.E.; Farnsworth, A.; Lunt, D.J.; Sagoo, N.; Pham, K.V.; Field, D.J. Climatic shifts drove major contractions in avian latitudinal distributions throughout the Cenozoic. Proc. Natl. Acad. Sci. USA 2019, 116, 12895-12900. [CrossRef] [PubMed]

92. Mourer-Chauviré, C. The Archaeotrogonidae of the Eocene and Oligocene Phosphorites du Quercy (France). Contrib. Sci. 1980, 330, 17-31.

93. Mayr, G. A postcranial skeleton of Palaeopsittacus Harrison, 1982 (Aves incertae sedis) from the middle Eocene of Messel (Germany). Oryctos 2002, 4, 75-82.

94. Martin, G.; Rojas, L.M.; Ramírez, Y.; McNeil, R. The eyes of oilbirds (Steatornis caripensis): Pushing at the limits of sensitivity. Naturwissenschaften 2004, 91, 26-29. [CrossRef]

95. Rojas, L.M.; Ramírez, Y.; McNeil, R.; Mitchell, M.; Marín, G. Retinal morphology and electrophysiology of two Caprimulgiformes birds: The cave-living and nocturnal Oilbird (Steatornis caripensis), and the crepuscularly and nocturnally foraging Common Pauraque (Nyctidromus albicollis). Brain. Behav. Evol. 2004, 64, 19-33. [CrossRef]

96. Snow, D.W. The natural history of the Oilbird, Steatornis caripensis, in Trinidad, W.I. part 2: Population, breeding ecology and food. Zoologica 1962, 47, 199-221.

97. Serventy, D.L. Feeding methods of Podargus: With remarks on the possible causes of its aberrant habits. Emu Austral Ornithol. 1936, 36, 74-90. [CrossRef]

98. Cracraft, J. Avian higher-level relationships and classification: Nonpasseriforms. In The Howard and Moore Complete Checklist of Birds of the World; Dickinson, E.C., Remsen, J.V., Eds.; Aves Press: Eastbourne, UK, 2013; pp. xxi-xliii.

99. Gill, F.; Donsker, D. IOC World Bird List (v9.2). Available online: https://www.worldbirdnames.org (accessed on 3 August 2019).

100. Chesser, R.T.; Burns, K.J.; Cicero, C.; Dunn, J.L.; Kratter, A.W.; Lovette, I.J.; Rasmussen, P.J.; Remsen, J.V.; Stotz, D.F.; Winger, B.M.; et al. AOU Checklist of North and Middle American Birds. Available online: http://checklist.aou.org/taxa (accessed on 3 August 2019).

101. De Q. Piacentini, V.; Aleixo, A.; Agne, C.E.; Maurício, G.N.; Pacheco, J.F.; Bravo, G.A.; Brito, G.R.R.; Naka, L.N.; Olmos, F.; Posso, S.; et al. Annotated checklist of the birds of Brazil by the Brazilian Ornithological Records Committee. Braz. J. Ornithol. 2015, 23, 91-298.

102. Cau, A. The assembly of the avian body plan: A 160-million-year long process. Boll. Soc. Paleontol. Ital. 2018, 57, 1-25.

103. Nesbitt, S.J. The early evolution of archosaurs: Relationships and the origin of major clades. Bull. Am. Mus. Nat. Hist. 2011, 352, 1-292. [CrossRef]

104. Baird, S.F. Catalogue of North American Birds, Chiefly in the Museum of the Smithsonian Institution; Smithsonian Institution: Washington, DC, USA, 1858.

105. Huxley, T.H. On the classification of birds: And on the taxonomic value of the modifications of certain of the cranial bones observable in that class. Proc. Zool. Soc. Lond. 1867, 35, 415-472.

106. Ridgway, R. Nomenclature of North American Birds Chiefly Contained in the United States National Museum; United States Government Publishing Office: Washington, DC, USA, 1881.

107. Ksepka, D.T.; Clarke, J.A. Affinities of Palaeospiza bella and the phylogeny and biogeography of mousebirds (Coliiformes). Auk 2009, 126, 245-259. [CrossRef]

108. Vigors, N.A. Observations on the natural affinities that connect the orders and families of birds. Trans. Linn. Soc. 1825, 14, 395-517. [CrossRef]

109. Sharpe, R.B. A Review of Recent Attempts to Classify Birds; Office of the Congress: Budapest, Hungary, 1891.

110. ICZN. International Code of Zoological Nomenclature; The International Trust for Zoological Nomenclature: London, UK, 1999.

111. Bonaparte, C.L. Catalogo metodico degli uccelli Europei (continuazione). Nuovi Ann. Sci. Nat. 1842, 8, 134-149.

112. Yuri, T.; Kimball, R.; Harshman, J.; Bowie, R.; Braun, M.; Chojnowski, J.; Han, K.-L.; Hackett, S.; Huddleston, C.; Moore, W.; et al. Parsimony and model-based analyses of indels in avian nuclear genes reveal congruent and incongruent phylogenetic signals. Biology 2013, 2, 419-444. [CrossRef]

113. Chenu, J.C.; des Murs, M.A.P. Encyclopédie D'histoire Naturelle; Maresq: Paris, France, 1851.

114. White, N.D.; Mitter, C.; Braun, M.J. Ultraconserved elements resolve the phylogeny of potoos (Aves: Nyctibiidae). J. Avian Biol. 2017, 48, 872-880. [CrossRef] 
115. Mathews, G.M. The Birds of Australia; Witherby \& Co.: London, UK, 1918.

116. Bonaparte, C.L. Synopsis vertebratorum systematis. Nuovi Ann. Sci. Nat. Bologna 1838, 1, 105-133.

117. Sibley, C.G.; Ahlquist, J.E.; Monroe, B.L. A classification of the living birds of the world based on DNA-DNA hybridization studies. Auk 1988, 105, 409-423.

118. Simonetta, A.M. Cinesi e morfologia del cranio negli Ucelli non passeriformi. Studio su varie tendenze evolative. Part II-Striges, Caprimulgiformes ed Apodiformes. Arch. Zool. Ital. 1967, 52, 1-35.

119. Bonaparte, C.L. Classification ornithologique par séries. Comptes Rendus Acad. Sci. 1853, 37, 641-647.

120. Dumbacher, J. Phylogeny of the owlet-nightjars (Aves: Aegothelidae) based on mitochondrial DNA sequence. Mol. Phylogenet. Evol. 2003, 29, 540-549. [CrossRef]

121. Peters, J.L. Check-List of Birds of the World; Harvard University Press: Cambridge, MA, USA, 1940.

122. McGuire, J.A.; Witt, C.C.; Remsen, J.V.; Corl, A.; Rabosky, D.L.; Altshuler, D.L.; Dudley, R. Molecular phylogenetics and the diversification of hummingbirds. Curr. Biol. 2014, 24, 910-916. [CrossRef]

123. Oberholser, H.C. The status of the generic name Hemiprocne Nitzsch. Proc. Biol. Soc. Wash. 1906, 19, 67-69.

124. Olphe-Galliard, L. Contributions à la Faune Ornithologique de l'Europe Occidentale; L. Lasserre: Bayonne, France, 1887.

125. Price, J.J.; Johnson, K.P.; Bush, S.E.; Clayton, D.H. Phylogenetic relationships of the Papuan Swiftlet Aerodramus papuensis and implications for the evolution of avian echolocation. Ibis 2005, 147, 790-796. [CrossRef]

126. Thomassen, H.A.; den Tex, R.-J.; de Bakker, M.A.G.; Povel, G.D.E. Phylogenetic relationships amongst swifts and swiftlets: A multi locus approach. Mol. Phylogenet. Evol. 2005, 37, 264-277. [CrossRef]

127. Päckert, M.; Martens, J.; Wink, M.; Feigl, A.; Tietze, D.T. Molecular phylogeny of Old World swifts (Aves: Apodiformes, Apodidae, Apus and Tachymarptis) based on mitochondrial and nuclear markers. Mol. Phylogenet. Evol. 2012, 63, 606-616. [CrossRef]

(C) 2019 by the authors. Licensee MDPI, Basel, Switzerland. This article is an open access article distributed under the terms and conditions of the Creative Commons Attribution (CC BY) license (http://creativecommons.org/licenses/by/4.0/). 